\title{
Tüketicinin Nesnelerin Interneti Teknolojilerini Benimsemesi ve Bir Uygulama
}

Consumer's Adoption of the Internet of Things Technologies and an Application

Prof. Dr. Celal Hakan Kağnıcıoğlü - Arş. Gör. Haldun Çolak ${ }^{2}$

Başvuru Tarihi: 22.08.2019

Kabul Tarihi: 30.12.2019

\section{Öz}

Bu çalışmanın amacı tüketicilerin gelecekte Nesnelerin İnterneti (Nİ) teknolojilerinin kabulüne yönelik davranışsal niyetinin açıklanmasıdır. Bütünleşik Teknoloji Kabul ve Kullanım Teorisi 2'de yer alan Performans Beklentisi, Çaba Beklentisi, Sosyal Etki, Hazsal Motivasyon ve Alışkanlık değişkenlerine Güven ile Güvenlik ve Mahremiyet değişkenleri eklenmiştir. Ayrıca moderatör etkisine bakmak amacıyla Teknoloji Hazır Olma İndeksi de çalışmada yer almaktadır. 377 katılımcıdan elde edilen veriler PLS-Yapısal Eşitlik Modellemesi yöntemiyle analiz edilmiştir. Bulgulara göre davranısssal niyete ait $R^{2}$ yüksek kabul edilebilecek bir değer olan 0,60 olarak bulunmuştur. Ayrıca tüketicilerin mevcut akıll cihazlarla girdikleri etkileşimleri sonucu sahip oldukları deneyim, onların yeni teknolojilere de alışkanlık kazanacakları inancını yansıtmakta ve dolayısıyla bu teknolojileri benimseyebileceklerini göstermektedir. Güven değişkeninin tüketicilerin bu teknolojilerden beklentilerini karşılamasında önemli bir değişken olduğu ortaya çıkmaktadır. Her ne kadar güvenlik ve mahremiyetin DN üzerinde doğrudan etkisi tespit edilemese de, hazsal motivasyonun tam aracılı etkisiyle, DN üzerinde pozitif ve anlamlı etkisi saptanmıştır. Tüketicilerin Nİ teknolojileriyle ilişkili veri mahremiyetinin korunması gibi konularda yeteri kadar bilgi sahibi olmadıkları anlaşılırken, Nİ teknolojilerinin kullanımı ile elde edilecek hazza yönelik inanç tüketicilerin veri mahremiyetine yönelik korkularını azaltmaktadır. Öte yandan tüketicilerin teknolojiye hazır olma seviyeleri yükseldikçe daha fazla haz alma, algılanan faydada artış ve daha kolay bir kullanım algısının oluşacağı sonucu çıkmaktadır. Özgünlük katan diğer birçok gizil ilişki ile birlikte bu çalışma, gelecekte bu teknolojilerin tüketiciler tarafından kabulü noktasında hem teorik hem de uygulamaya ışı tutması açısından önemli sonuçlar elde edilmesini să̆lamıştır.

Anahtar Kelimeler: Nesnelerin İnterneti, Teknoloji Kabulü, BTKKT 2, Tüketiciler

\footnotetext{
${ }^{1}$ Anadolu Üniversitesi İşletme Fakültesi, chkagnic@anadolu.edu.tr, ORCID: 0000-0003-4369-6063

${ }^{2}$ Anadolu Üniversitesi İktisadi ve İdari Bilimler Fakültesi, halduncolak@anadolu.edu.tr, ORCID: 0000-0001-7164-3538
} 


\section{Abstract}

The purpose of this study is to explain the behavioural intention towards consumers' adoption of The Internet of Things (IoT) technologies in the future. Accordingly, to those variables which are in the original model (Unified Technology Acceptance and Usage Theory 2) namely Performance Expectacy, Effort Expectacy, Social Influence, Hedonic Motivation and Habit, we add two new variables Trust and Security and Privacy. Besides, to examine the moderating effect, Technology Readiness Index is included in model. The data derived from 377 participants are analysed with PLS-Structural Equation Modelling method. According to findings, behavioural intention's $R^{2}$ is calculated as 0,60 which is quite high. Furthermore, consumers' experience retrieved from the interaction with current smart devices reflects the believe that they will gain habit from new technologies and also shows that they may adopt those new technologies. Trust is also an important variable meeting the expectations of consumers from this technology. Eventhough, it hasnt been determined that security and privacy has direct and significant effect on behavioural intention, it is understood that security and privacy has direct affect on behavioural intention via full mediation effect of medonic motivation. While it is implied that consumers dont have any information related to security and privacy issues of IoT, their fears towards information privacy decreases as their believe that they gain more hedonic pleasure increases. Besides as the readiness level of consumers increases, they develop perception of more enjoyment, increased usefulness and easier usage. Consequently, with the other latent relationships adding originality, this study gives important results illuminating both theorical and practical sides regarding future adoption of IoT technologies by consumers.

Keywords: The Internet of Things, Technology Adoption, UTAUT 2, Consumers

\section{Giriş}

Günümüzde sürekli gelişen pazarlar ve artan küresel rekabet endüstri üretiminin de farklı bir noktaya gelmesini sağlamıştır. Bu bağlamda Nesnelerin İnterneti (Nİ) teknolojileri başta olmak üzere birçok gelişmiş bilgi ve iletişim teknolojileri, sözü edilen endüstri üretimini Endüstri 4.0 olarak bilinen kavram çerçevesinde şekillendirmiştir. Bu noktada Endüstri 4.0 ile yeni ürün geliştirme süreçlerinde kısalma, kişiye özel üretime yönelik talebin oluşması, esnekliğin geliştirilmesi ve hammadde sıkıntılarının giderilmesi gibi gereksinimlerin hızlı bir şekilde giderilmesi mümkün olmuştur (Lasi vd., 2014). Endüstri 4.0'ın getirdiği firsatları değerlendirebilen işletmeler rekabette bir adım öne çıkarken, tüketici boyutu dikkate alındığında birçok sosyal ve tüketime yönelik desenin de bu gelişmelerden etkilendiğini söylemek mümkündür. Bu etkiyi yaratan en önemli etken ise bütün nesnelerin internet üzerinden birbirleriyle ve kullanıcılarla iletişimini mümkün kılan Nİ teknolojileri olmaktadır. Nesnelerin İnterneti (NI) teknolojileri, insanlara daha yenilikçi ve akıllı ürün ve hizmetler sağlarken aynı zamanda birbirleriyle ve kullanıcılarla internet üzerinden iletişim kurabilme olanağı sunabilmekte ve akıllı cihazlar sayesinde insanların hayatlarını kolaylaştırabilmektedir. Nİ teknolojileri sağlık, akıllı ev ve otomasyonları, akıllı şebekeler, askeriye, otomotiv, taşıma ve lojistik, çevre düzenleme ve havacılık gibi birçok alanda yaygın şekilde kullanılırken, tüketici 
ürünleri açısından bakıldığında başlangıç aşamasında olduğu söylenebilir. Ancak Nİ teknolojilerinin sahip oldukları yetenekler ve işletmelerin bu teknolojilere yapacağı yatırımlar düşünüldüğünde bahsedilen çerçeve daha da genişleyecektir. Örnek olarak Cisco (2013)'e göre, 2013 yılı ile 2022 yılları arasında Nİ teknolojilerinin şirketler ve endüstriler için 14.4 trilyon dolarlık değer yaratacağı beklenmektedir. Dolayısıyla her nesnenin ya da ürünün Nİnin getireceği değişimden etkilenebilmesi söz konusu olacaktır. Bu doğrultuda Nİ teknolojileri sahip oldukları yenilikler ve sundukları olanaklarla, günlük yaşamlarında tüketici davranışlarını etkileyebilecektir (Gao ve Bai, 2014). Nİ teknolojilerinin gelecekte tüketiciler tarafından benimsenmesi ve kabulü noktasında, tüketiciyi motive eden faktörlerin neler olduğunun da ortaya konulması, çizilen çerçevede önemli bir araştırma konusu olarak karşımıza çıkmaktadır. Dolayısıyla mevcut çalışmanın amacı yeni teknolojilerin kabulüne yönelik en önemli göstergelerden birisi olan Davranışsal Niyetin (DN) Nİ çerçevesinde oluşumu ve nelerden etkilendiğinin ortaya konulmasıdır. Mevcut çalışmada da BTKKT 2 modeli Nİ konseptine uygun olacak şekilde kullanılarak, DN üzerinde etkili olduğu düşünülen faktörler incelenmiştir.

\section{Literatür Analizi}

\section{Nesnelerin Interneti (The Internet of Things)}

Nİ tüm nesnelerin internete bağlı olduğu ve en az insan etkileşimi ile kendi aralarında iletişim kurabildikleri ve kullanıcıları çevreleyen bir dünyayı ifade etmektedir. Nİ teknolojisi 3 temel katmandan oluşmaktadır. Bu temel katmanlar cihaz katmanı, bağlantı katmanı ve uygulama katmanı olarak bilinmektedir. Cihaz katmanı çeşitli sensörler ve veri toplayıcılardan oluşurken bağlantı katmanı ise cihaz katmanında toplanan verilerin uygulama katmanına iletilmesini sağlamaktadır (AlHogail ve AlShahrani, 2019). Son kullanıcı ile etkileşime geçen uygulama katmanında ise çeşitli hizmet ve uygulamalar yer almaktadır.

Mevcut literatür incelendiğinde çalışmaların genellikle Nİ teknolojilerinin teknik, güvenlik ve çeşitli alt sistem özellikleri üzerinde yoğunlaştığı anlaşılmaktadır (Ammar, Rusello ve Crispo, 2018; Alaba vd., 2017; Gago, Moyano ve Lopez, 2017; Gong 2016; Mohammadzadeh vd., 2018; Silva, Khan ve Han, 2018). Ancak Gao ve Bai (2014) ifade ettiği üzere tüketicinin karakteristik özelliklerinin ve sosyal özelliklerinin, tüketicilerin Nİ teknolojilerini kabulü üzerindeki etkilerini inceleyen çalışma sayısı oldukça az olmaktadır. Dolayısıyla bu çalışma tüketicinin Ni teknolojilerini kabulüyle ilişkili olarak etkili olan faktörleri belirleyen ve kabul davranışını açıllayan bir model geliştirme ve testini hedeflemektedir.

\section{Teknoloji Kabulü ve Nesnelerin İnterneti}

Kabul davranışının incelenmesine yönelik olarak Gerekçeli Davranış Teorisi (GDT), Planlı Davranış Teorisi (PDT), Sosyal Biliş Teorisi (SBT), İnovasyon Yayılma Teorisi (İYT), Teknoloji Kabul Modeli (TKM) ve Bütünleşik Teknoloji Kabul ve Kullanım Teorisi 1 (BTKKT 1) gibi birçok teori ve model geliştirilmiştir. Araştırmacılar bu teoriler ve ilişkili modellerle kullanıcıların teknolojik ürünleri ya da sistemleri neden benimsedikleri ya da hangi faktörlerin bu benimseme davranışında rol oynadıklarını incelemişlerdir. Bu bağlamda Venkatesh, Thong ve Xu (2012) BTKKT 1'de yer alan Performans Beklentisi (PB), Çaba Beklentisi (ÇB), Sosyal Etki (SE) ve Düzenleyici Koşullar (DK) değişkenlerine; Hazsal Motivasyon (HM), Fiyat Değeri 
(FD) ve Alışkanlık (AL) değişkenlerini ekleyerek modeli tüketici konseptine uygun hale getirerek BTKKT 2'yi ortaya çıkarmışlardır. Bu yönüyle BTKKT 2 tüketicinin yeni teknolojileri kabulünü ve kullanımını açıklamasına yönelik geliştirilen en kapsamlı teori olarak kabul edilmektedir (Gao, Li ve Luo, 2015). Teknoloji kabulüne yönelik yapılan çalışmalarda kullanılan bir diğer teori ise Parasuraman (2000) tarafından geliştirilen Teknoloji Hazır Olma İndeksidir (THİ). Bu indeks tüketicilerin teknolojilere karşı sahip oldukları kişilik özelliklerini yansıtmaktadır ve iyimserlik, yenilikçilik, rahatsızlık ve güvensizlik olmak üzere 4 alt boyuttan oluşmaktadır. İyimserlik (optimism) ve yenilikçilik (innovativeness) teknolojiye karşı hazır olmayı ya da pozitif özellikleri ifade ederken, rahatsızlı (discomfort) ve güvensizlik (insecurity) teknolojiye karşı hazır olmamayı ya da olumsuz özellikleri ifade etmektedir.

Yeni teknolojilerin, sistemlerin ve ürünlerin kabulüne yönelik olarak birçok alanda DN üzerinde etkili olan faktörler belirlenmeye çalışılmıştır (Wong vd., 2014; Gaitan, Peral ve Jerenimo, 2013; Gao, Li ve Luo; 2015). Bazı çalışmalar ise Güven (GÜ) değişkenini de DN üzerinde etkili olması noktasında incelemiştir (El-Masri ve Tarhini, 2017; Mardjo, 2018). Bu çalışmalarda GÜ’nin DN'i açlklamada önemli bir değişken olduğu ortaya konmuştur. Söz konusu Nİ teknolojilerinin kabulü ve kullanımı olduğunda ise gerçekleştirilen az sayıda çalışmanın TKM'ni temel alarak Nİ konseptine uygun yeni model arayışında olduğu görülmektedir (Gao ve Bai, 2014; Attie ve Waarden, 2018; AlHogial ve AlShahrani, 2018).

Nİ teknolojilerinin kabulüne yönelik çalışmalarda sadece kabul teorilerinde yer alan değişkenlerin yeterli olamayacağı düşünülmektedir. Nİ teknolojileri sahip oldukları birçok yeteneğin yanında özellikle kişisel verilerin güvenliği ve kullanım güvenliğine yönelik tartışmaları da beraberinde getirmektedir. Dolayısıyla güven (GÜ) ile güvenlik ve mahremiyete (GVM) ilişkin konular Nİ konsepti çerçevesinde önemli ve incelenmesi gereken değişkenler olarak kabul edilmelidir. Söz konusu sistem ve mahremiyet güvenliği gibi kullanıcının öznel güvenlik algısı olduğunda literatürde bazı çalışmaların GVM'in DN üzerinde etkisi olduğunu tartışırken (Shin, 2010), bazı çalışmaların ise bu iki faktör arasında anlamlı bir ilişkinin olmadığını tartışmışlardır (Lian, 2015; Morosan ve DeFranco). Kişinin kontrol etme ve çevresindeki dünyayı tanıma ihtiyacıyla ilişkilendirilebilecek güven (GÜ) yeni teknolojilerin kabulüne yönelik çalışmalarda ilgi çeken faktörlerden birisi olmaya başlamıştır. Özellikle akıllı cihazlar, çeşitli teknolojik sistemler ve birçok diğer yeni teknolojinin kabulü noktasında güvenin davranışsal niyet üzerindeki etkisi saptanmıştır (Kaushik vd., 2015; Cabanillas, Marinkovic ve Kalinic, 2017; Aldossari ve Sidorova, 2018).

Teknoloji hazır olma indeksi başta TKM olmak üzere birçok teori dâhilinde kullanılarak teknoloji kabulü çerçevesinde davranışsal niyet üzerindeki dolaylı ve doğrudan etkileri incelenmiştir (Elliott, Meng ve Hall, 2012; Kuo, Liu ve Ma, 2013; Rahman vd., 2017). Bu çalışma kapsamında ise teknoloji hazır olma indeksinin moderatör etkisi incelenmek istenmektedir. $\mathrm{Bu}$ bağlamda yapılan alanyazın taraması sonucunda ilişkili tek çalışma Tsourela ve Roumeliotis (2015) olmaktadır. Çalışma sonuçlarına göre teknoloji hazır olma indeksi SE ve PB ile DN arasındaki ilişkide moderatör etkiye sahip olmaktadır. 
Nİ teknolojileri sahip oldukları yenilikler ve yeteneklerle tüketicilere eşsiz firsatlar sunarak onların hayatlarını ve günlük tercihlerini değiştirmeyi hedeflemektedir. Sonuç olarak Nİ teknolojilerinin vaat ettiği ve tüketim alışkanlıklarını değiştirecek olan yeni özellikler düşünüldüğünde, tüketicilerin bu teknolojileri kabulü noktasında kapsamlı ölçüm modellerine ihtiyaç olduğu düşünülmektedir. Bu noktada mevcut çalışmada BTKKT 2 çerçevesinde GÜ ve GVM modele eklenerek Nİ teknolojilerine tüketicinin hazır olup olmadığ 1 DN açıklanarak incelenecektir.

\section{Kavramsal Çerçeve ve Hipotezler}

Literatüre benzer şekilde davranışsal niyet bu çalışmada tüketici kabulü açısından temel belirleyici olarak kabul edilmektedir (Venkatesh ve Davis, 2000; Venkatesh vd., 2003). Buradaki temel motivasyon davranışsal niyetin mevcut kullanım davranışının en önemli açıklayıcısı olmasıdır. Bu bağlamda tüketicilerin gelecekte Nİ teknolojilerini kullanmalarına yönelik tahmin açısından davranışsal niyetin açıklanması önemli olmaktadır. Şekil 1 Nİ teknolojilerinin kabulüne yönelik davranışsal niyet ve belirleyicileri arasındaki ilişkiyi göstermektedir. Teorik açıdan bakıldığında geçmiş çalışmaların, kullanıcıların inançları ve davranışsal niyet arasındaki ilişki noktasında güçlü bir ilişkisini açıkladığı görülmektedir (Baudier, Ammi ve Rouchon, 2018; El-Masri ve Tarhini, 2017; Gaitan, Peral ve Jerenimo, 2013). Bu yüzden yine teorik olarak davranışsal niyetin Nì kabul davranışının açıklanması açısından tek bir bağımlı değişken olarak ele alınması gerekçelendirilebilmektedir (Gao ve Bai, 2014). Ayrıca çalışmada şu 3 araştırma sorusuna da cevap aranmaktadır:

- Tüketim ve sosyal alışkanlıklar anlamında birçok deseni derinden etkileyeceği vurgulanan Nİ teknolojilerinin kabulü noktasında tüketici ne kadar hazır?

- Kullanım davranışısın en önemli göstergelerinden olan Davranışsal Niyet hangi faktörlerce belirlenmektedir?

- $\quad \mathrm{PB}, \mathrm{ÇB}, \mathrm{SE}, \mathrm{GÜ}, \mathrm{AL}, \mathrm{HM}$ ve GVM ile DN arasındaki ilişki teknolojiye hazır olma seviyesine göre değişiklik göstermekte midir? 


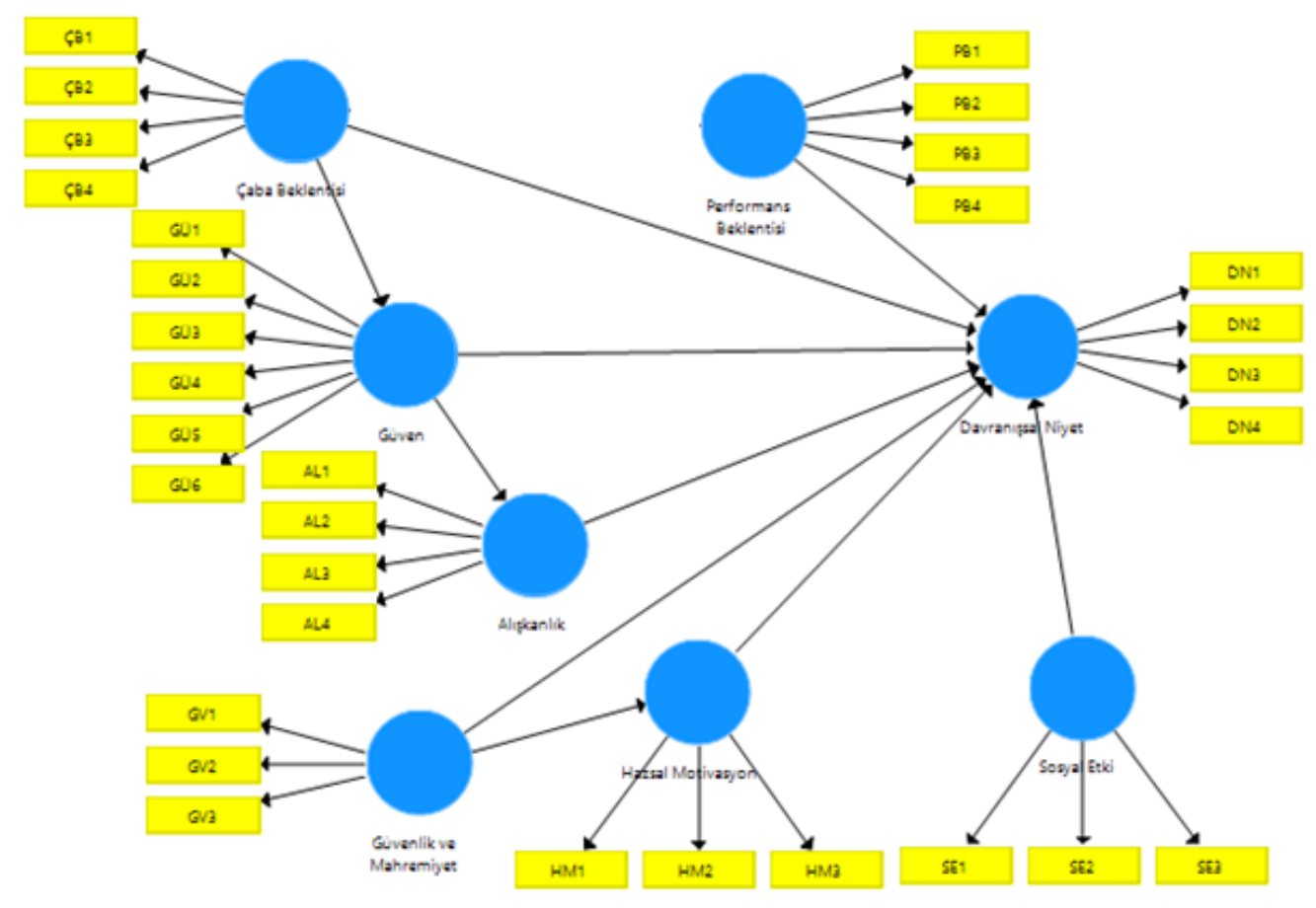

Şekil 1. Nİ Kabul Modeli

Tablo 1. Modelde Yer Alan Değişkenlere İlişkin Tanımlamalar

\begin{tabular}{|c|c|c|}
\hline Değişiken & Tanım & Yazar \\
\hline Çaba Beklentisi (ÇB) & $\begin{array}{l}\text { Sistem } \\
\text { tüketici tarafınımınının algılanma derecesi }\end{array}$ & Venkatesh vd., (2003) \\
\hline Sosyal Etki (SE) & $\begin{array}{l}\text { Bireyin kendisi için önemli olan } \\
\text { kişilerin, yeni sistemi kullanmasını } \\
\text { istemeleri algısı }\end{array}$ & Venkatesh vd., (2003) \\
\hline Hazsal Motivasyon (HM) & $\begin{array}{l}\text { Teknoloji kullanımından elde edilen } \\
\text { keyif ve haz }\end{array}$ & Brown ve Venkatesh, (2005) \\
\hline Alışkanlık (AL) & $\begin{array}{l}\text { Kişinin öğrenme dolayısıyla otomatik } \\
\text { olarak sergileme eğiliminde olduğu } \\
\text { davranış boyutu }\end{array}$ & $\begin{array}{l}\text { Limayem, Hirt ve Cheung, } \\
\text { (2007) }\end{array}$ \\
\hline Performans Beklentisi (PB) & $\begin{array}{l}\text { Kullanılan sistemin kişinin iş } \\
\text { performansını geliştirmesine yardımcı } \\
\text { olacağına yönelik inancının derecesi }\end{array}$ & Venkatesh vd., (2003) \\
\hline Güven (GÜ) & $\begin{array}{l}\text { Bir başkasının ya da bir sistemin } \\
\text { durumdan avantaj sağlayıp firsatçı bir } \\
\text { şekilde } \\
\text { beklentisidir }\end{array}$ & $\begin{array}{c}\text { Gefen, Karahanna ve Straub } \\
\text { (2003) }\end{array}$ \\
\hline Güvenlik (GVM) & $\begin{array}{l}\text { Kişinin Nİ hizmetleri ya da ürünlerinin } \\
\text { risk taşımadığına olan inanç boyutudur }\end{array}$ & $\begin{array}{l}\text { (AlHogial ve AlShahrani, } \\
\text { 2019) }\end{array}$ \\
\hline
\end{tabular}




\section{Sosyal Etki ve Davranışsal Niyet}

Venkatesh vd., (2003) sosyal etkiyi bireyin teknolojik ürünleri satın almadan önce kendisi için önemli olarak gördüğü bireylerin görüşlerine başvurması ya da onların davranışa yönelik inançlarıyla ilgili algılama derecesi olarak tanımlamaktadır. Birey kendisine yakın gördügü ya da fikirlerini önemsediği akrabaları, arkadaşları ve sosyal çevresinde yer alan diğer kişilerin görüşlerine başvurabilmektedir. Bu açıdan bakıldığında sosyal etki Gerekçeli Davranış Teorisi ve Planlı Davranış Teorisinde yer alan öznel normlara benzemektedir. Yeni teknolojilerin kabulü noktasında gerçekleştirilen birçok çalışmada sosyal etkinin davranışsal niyet üzerinde doğrudan ve pozitif etkisinin olduğu bulunmuştur ( $\mathrm{Wu}$, Wu ve Chang, 2016; Verkijika, 2018). $\mathrm{Bu}$ çalışmada da sosyal etkinin davranışsal niyet üzerinde pozitif bir etkisinin olduğu öngörülmektedir. Dolayısıyla ilişkili hipotez:

H1: Sosyal etki, Nİ teknolojilerinin kabulüne yönelik davranışsal niyet üzerinde anlamlı bir etkiye sahiptir.

\section{Performans Beklentisi ve Davranıssal Niyet}

Nİ teknolojilerinin kullanımının kişinin günlük yaşantısında kendisine fayda sağlayacağına yönelik inancını yansıtan performans beklentisi BTKKT 1'de davranışsal niyetin açılanmasında etkili olan en önemli faktör olarak belirlenmiştir (Venkatesh vd., 2003). Literatürde çeşitli teknolojilerin kabul davranışına yönelik yapılan çalışmalarda da benzer sonuçlara ulaşılmıştır (Baptista ve Oliviera, 2015; Chipeva vd., 2018). İYT’de ifade edildiği üzere tüketiciler yeni bir teknolojik ürünün ya da hizmetin benimsenmesi noktasında bu ürün ya da hizmetin mevcut ürün ya da hizmetlere kıyaslandığında nispeten avantaj sağlamasını beklemektedirler (Gao ve Bai, 2014). Nİ teknolojileri sahip oldukları eşsiz yenilikler ve günlük yaşanacak problemlere karşı sürekli yeni çözümler getirebilme yeteneğine sahip oldukları için, tüketicinin bu anlamda sağlayacağı toplam faydaya yönelik inancı da yüksek olacaktır. Dolayısıyla ilişkili hipotez şu şekilde olmaktadır:

H2: Performans beklentisi, Nİ teknolojilerinin kabulüne yönelik davranışsal niyet üzerinde anlamlı bir etkiye sahiptir.

\section{Hazsal Motivasyon ve Davranıssal Niyet}

Venkatesh, Thong ve Xu (2012) hazsal motivasyonun davranışsal niyet üzerinde pozitif ve anlamlı bir etkisinin olduğunu bulmuşlardır. Benzer sonuçlara literatürdeki birçok çalışmada rastlanabilir: Gao, Li ve Luo (2015) giyilebilir fitness cihazlarının kabulü; akıllı telefonların kabulü Simanjuntak ve Ramantoko (2016); iletişim ve bilgi teknolojilerinin benimsenmesi Chipeva vd., 2018; internet bankacılığı uygulamalarının kullanıcılar tarafından kabulü Alalwan vd., (2017). Nİ teknolojileri insanların yaşamlarını kolaylaştıracak birçok özelliğe sahipken aynı zamanda kullanıcıların eğlenceli vakit geçirmesini sağlayacak uygulamalar da sunmaktadır. Hazsal motivasyon diğer gerekçeli inançlardan bağımsız olarak tüketicinin duygusal motivasyonunun keşfedilmesini sağlarken aynı zamanda tüketicinin yeni nesil teknolojileri kabullerini de arttırmaktadır (Wu, Wu ve Chang, 2016). Dolayısıyla bu çalışma kapsamında ilişkili hipotez şu şekilde olmaktadır: 
H3: Hazsal Motivasyon, gelecekte Nİ teknolojilerinin kabulüne yönelik davranışsal niyet üzerinde anlamlı bir etkiye sahiptir.

\section{Güven, Alışkanlık ve Davranışsal Niyet}

Alışkanlık genellikle teknolojiye yönelik geçmiş davranışların ve deneyimlerin sonuçlarını yansıtmaktadır (Baudier, Ammi ve Rouchon, 2018). Bu bağlamda yapılan çalışma neticesinde tüketicilerin mevcut akıllı teknolojilerle geliştirdikleri deneyimleri sonucunda bu teknolojilerin kullanımına bağımlı hale geldiklerinden Nİ teknolojilerinin gelecekte kullanımına yönelik olarak alışkanlık kazanacaklarına yönelik inançları da yüksek olacaktır. Ek olarak Ajzen ve Fishbein (2005)'e göre geçmiş deneyimler sonucu elde edilen geribildirimlerin gelecekteki birçok davranışı ve inancı şekillendirmektedir. Venkatesh, Thong ve Xu (2012) alışkanlığın davranışsal niyet üzerinde güçlü ve anlamlı bir etkisinin olduğunu bulmuştur. Benzer şekilde Herrero ve Martin (2017) sosyal ağların kullanıcılar tarafından benimsenmesi noktasında alışkanlığın niyet üzerinde önemli bir etkisinin olduğunu bulmuşlardır.

Nİ teknolojilerinin kabulü çerçevesinde çok az sayıda çalışma güvenin davranışsal niyet üzerindeki etkisini incelemiştir (Belanche, Casalo ve Flavian, 2012; Gao ve Bai, 2014; Coughlan vd., 2012; AlHogail, 2018; AlHogail ve AlShahrani, 2019). Bu noktada ayrıca eğilimin TKM ve diğer modellerin bütünleşik bir şekilde kullanılarak diğer teknolojik ürün ve servislerin kabulüne yönelik güvenin incelenmesi şeklinde olduğu anlaşılmaktadır (Wei vd., 2009; Kaushik, Agrawal ve Rahman, 2015; Cabanillas, Marinkovic ve Kalinic, 2017). Ancak güven özellikle Nİ teknolojileri gibi beraberinde birçok avantajla beraber riskleri de getiren karmaşık sistemlerin tüketiciler tarafından kabulü noktasında önemli bir faktör olmaktadır. Güven esasında belirsizlikle ilişkili olduğu için, tüketicilerin geçmiş deneyimlerinden gelen geribildirimleri neticesinde sahip oldukları inançlar aynı zamanda gelecekte yeni teknolojilerin benimsenmesine yönelik güvenin oluşumunu da etkileyecektir. Dolayısıyla geribildirimler neticesinde yeni teknolojilerin kullanımına yönelik tüketici yüksek bir güven eğiliminde olursa bu da o teknolojilere bağımlı hale gelebilecekleri inançlarını da arttıracaktır. Buna paralel olarak Ouellette ve Wood (1998)'a göre eğer bir davranış alışkanlık haline geldiyse, gelecekte bu davranışın tekrarlanması bilinçli bir karara dayanacaktır. Bu bilinçli karar da temelde güvenden kaynaklanmaktadır. Sonuç olarak tüketicilerin mevcut akıllı ürün ve sistemlerle olan deneyimleri sonucunda sahip oldukları güvenleri ve inançları onların gelecekte Nİ teknolojilerine bağımlı hale gelebilecekleri inançlarını da arttıracaktır. Dolayısıyla ilişkili hipotez şu şekilde olmaktadır:

H4: Güven gelecekte Nİ teknolojilerinin kabulüne yönelik davranışsal niyeti alışkanlık aracılığıla etkilemektedir.

\section{Güvenlik ve Mahremiyet, Hazsal Motivasyon ve Davranışsal Niyet}

Güvenlik ve mahremiyete ilişkin konular Nİ teknolojilerinin gelişmesiyle birlikte tartışma yaratan kavramlar olarak karşımıza çıkmaktadır. Güvenlik daha çok ürün ya da hizmetin risk içermeden kullanımını ifade ederken, mahremiyet ise kişisel verilerin güvenliği ile ilgili olmaktadır. Güvenlik ve mahremiyete ilişkin faktörler yeni teknolojilerin kabulünde önemli rol 
oynamaktadır (AlHogail, 2018; Yıldırım ve Eldin, 2018; Falcone ve Sapienza, 2018) ve benimseme davranışının artması için kullanıcıların teknolojik ürün ve sistemleri kullanırken güvenli ve kişisel mahremiyetlerinin koruma altında olduğunu hissetmeleri gerekir. Ancak Nİ teknolojileri yoğun şekilde sensör ve diğer ileri teknolojilerin kullanımına dayandığı için, bu teknolojiler zamanla veriyi depolayıp işleyerek kendi güvenlik sistemlerini de yenileyebilmektedirler. Shin (2010) belirttiği üzere güvenlik ve mahremiyetin kullanılan teknolojiyle birlikte risk içermeyecek şekilde şirketler, markalar ya da devlet tarafından garanti altına alınması gerekmektedir. Dolayısıyla bu yönde kullanıcıda gelişecek pozitif bir eğilim, bu teknolojilerin kullanımı noktasında tüketicide herhangi bir belirsizlik ya da korku yaratmayacağından, kullanımdan daha fazla keyif almaları mümkün olacaktır. Hazsal motivasyon birçok çalışmada bilgi sistemleri ve yeni teknolojilerin kabulü noktasında önemli bir açıklayıcı olarak bulunmuştur (Brown ve Venkatesh, 2005; Venkatesh, Thong ve Xu, 2012). Deci ve Ryan (2011) tarafından geliştirilen öz belirleme (self-determination) teorisine göre kişiler içsel olarak giriştikleri eylemden keyif alma eğilimde olmaktadırlar. Dolayısıyla Nİ teknolojilerinin kullanımın keyif verici ve eğlenceli zaman geçirilmesi noktasında etkili olacağına yönelik inançlar benimseme davranışını da arttıracaktır. Bu noktada tüketicinin herhangi bir korku ya da endişe yaşamadan başka bir deyişle güvenlik ve mahremiyet konularında rahat olması gerektiği de önemli olmaktadır. Dolayısıyla riskten bağımsız olduğunu düşünen tüketiciler Nİ teknolojilerini kullanırken daha çok keyif alacaklardır. İlişkili hipotez ise şu şekildedir:

H5: Güvenlik ve mahremiyet, Nİ teknolojilerinin kabulüne yönelik davranışsal niyeti hazsal motivasyon aracılığıla etkilemektedir.

\section{Çaba Beklentisi, Güven ve Davranışsal Niyet}

Çaba beklentisi, tüketicinin Nİ teknolojilerini kullanımlarının çaba gerektirmeyeceğine yönelik inançlarını yansıtmaktadır. Bilgi sistemleri ve çeşitli teknolojilerin kullanımına yönelik gerçekleştirilen birçok çalışmada çaba beklentisinin davranışsal niyet üzerindeki etkisi desteklenmektedir (Macedo, 2017; Alalwan vd., 2017; Ameen, Willis ve Shah, 2018). Teorik olarak tüketicilerin Nİ teknolojilerinin kullanımını kolay olarak algılamaları onların bu teknolojileri benimsemelerini etkileyecektir. Bunun yanında kullanım kolaylı̆̆ı tüketiciye kontrol sağlayacağı için, başka bir ifadeyle tüketicinin sahip olduğu kontrol inancı aynı zamanda bu teknolojilere olan güveni de arttıracaktır. Bu noktada Ajzen (1991)'e göre bir davranışa ilişkin niyetin oluşmasında kişinin harcanacak çaba noktasındaki istekliliği de önemli olmaktadır. Bu isteklilik temelde kişinin öz yeterliliği (self-efficacy) ile şekillendiğinden, öz yeterlilik hedef aktiviteye yönelik harcanacak çabayı etkilemekte ve dolayısıyla niyet hedef aktivitenin gerçekleşmesine yönelik güvenden etkilenecektir. Bu noktada ilişkili hipotez şu şekilde oluşmaktadır:

H6: Çaba beklentisi gelecekte Nİ teknolojilerinin kabulüne yönelik davranışsal niyeti güven aracılığıla etkilemektedir. 


\section{Tasarım ve Yöntem}

Mevcut çalışma uygulamalı betimsel bir çalışmadır. Nİ teknolojileri her ne kadar henüz uygulamada yaygın bir biçimde kullanılmıyor olsa da, başta akıllı telefonlar olmak üzere, akıllı saatler ve akıllı gözlükler mevcut durumda Nİ teknolojileri kapsamında değerlendirilebilecek başlıca ürünler olarak karşımıza çıkmaktadır. Bu bağlamda anakütle herhangi bir akıllı cihaz kullanan kişiler olurken (Aksöz, 2018), kolayda örnekleme yöntemi kullanılarak Anadolu Üniversitesinin çeşitli fakültelerinden öğrenciler örneklem olarak belirlenmiştir. Veri toplama tekniği olarak anket kullanılmış olup geçerli anket sayısı 377'dir. Ölçek maddeleri Nİ teknolojilileri çerçevesinde uyarlanarak 5'li Likert tipinde hazırlanmıştır (1= Kesinlikle katılmıorum, 5= Kesinlikle katılıyorum). BTKKT 2 ölçek maddeleri Venkatesh, Thong ve Xu (2012), Güven maddeleri Gefen, Karahanna ve Straub (2003) ve Güvenlik maddeleri Chong ve Chan, (2012) çalışmalarından uyarlanmıştır. Ayrıca moderatör analizi için kullanılan teknoloji hazır olma indeksi alt boyutlarına ilişkin ölçek maddeleri de Shin ve Lee (2014) çalışmasından uyarlanmıştır.

Veriler 15 Ekim-28 Aralık tarihleri arasında toplanmıştır. Toplanan verilerin analizi ve oluşturulan modelin testi için ise PLS - Yapısal Eşitlik Modellemesi (PLS-YEM) tekniği kullanılmıştır. Verilerin analizi için SmartPLS 3.2.8 kullanılmıştır (Ringle vd., 2015). PLS ile yol analizi yapısal eşitlik modellemesinde kullanılan tekniklerden birisidir. Yapısal eşitlik modellemesi çok sayıda bağımlı ve bağımsız değişkenden oluşan karmaşık modellerin analizi için kullanılmaktadır. Bu noktada yapısal eşitlik modellemesi kovaryans temelli ve PLS (partial least square/en küçük kareler) olmak üzere ikiye ayrılmaktadır. PLS-YEM eş zamanlı olarak ölçüm modeli ve yapısal modeli test edebilmektedir. PLS-YEM araştırmada amacın odak noktası olan olguyu açıklamak olduğu durumlarda kullanılmasının faydalı olacağı ifade edilmektedir (Doğan, 2019). Eğer amaç bir teoriyi desteklemek ya da test etmek ise kovaryans temelli yapısal eşitlik modellemesi kullanılmalıdır. Bu noktada Simanjuntak ve Ramantoko (2016) yeni bir model geliştiriliyorsa ve modelde yer alan ilişkiler karmaşık bir yapıdaysa PLSYEM kullanımını önermektedirler. Çeşitli alanlarda yapılan çalışmalarda kabul görmüş bir yöntem olan PLS-YEM özellikle yeni teknolojilerin kabulüne yönelik yapılan çalışmalarda da ilgi görmeye başlamıştır (Henseler, Hubona ve Ray, 2015). Bütün bu açıklamalar ışığında bu çalışmada PLS-YEM kullanılmasının sebebi, çalışmanın amacının bir teori doğrulaması olmaktan ziyade Nİ teknolojilerinin benimsenmesinde etkili olan faktörlerin tahmin edilerek davranışsal niyetin açıklanması olmasıdır.

Burada dikkat edileceği üzere DK ve FD değişkenleri inceleme kapsamına alınmamıştır. Bunun nedeni ise Nİ teknolojileri olarak kabul edilebilecek ve tüketicinin deneyimleyebileceği ve dolayısıyla ölçüm yapılmasına imkan verebilecek teknik alt yapı ve yapı ekipmanlarının henüz mevcut olmamasıdır (Xiong ve Mei, 2016).

\section{Bulgular ve Tartışma}

PLS ile yapısal eşitlik modellemesi iki aşamadan oluşmaktadır: Ölçüm modelinin değerlendirilmesi ve yapısal modelin değerlendirilmesi. İlk aşamada içsel tutarlık, bileşik geçerlik ve ayrışma (diskriminant) geçerliği ile yapının güvenirlik ve geçerliği 
değerlendirilirken, ikinci aşamada ise yol katsayılarının büyüklüğü ve anlamlılığı incelenerek hipotezler test edilir (Hair vd., 2016). Bu doğrultuda Tablo 2'de yapıyla ilgili güvenirlik değerleri verilmiştir.

Sonuçlar incelendiğinde Kompozit Güvenirlik/Bileşik Güvenirlik ve Cronbach Alpha değerlerinin 0,70 eşik değerinden yüksek olduğu görülmektedir (Hair vd., 2016). Ayrıca bileşik geçerlik için bakılması gereken AVE (average variance extracted) değerlerinin de Fornell ve Larcker (1981) önerdiği üzere 0.5 eşik değerinin üzerinde olduğu görülmektedir. Dolayısıyla önerilen modelde yer alan yapıların güvenilir olduğu sonucuna ulaşılmaktadır.

Tablo 2. Yapı Güvenirliği ve Geçerliği

\begin{tabular}{|c|c|c|c|}
\hline & $\begin{array}{c}\text { Cronbach's } \\
\text { Alpha }\end{array}$ & $\begin{array}{c}\text { Birleşik } \\
\text { Güvenirlik }\end{array}$ & AVE \\
\hline Alışkanlık & 0,838 & 0,891 & 0,673 \\
\hline Davranışsal Niyet & 0,922 & 0,945 & 0,810 \\
\hline Güven & 0,893 & 0,918 & 0,652 \\
\hline Güvenlik ve Mahremiyet & 0,903 & 0,939 & 0,837 \\
\hline Hazsal Motivasyon & 0,960 & 0,974 & 0,927 \\
\hline Performans Beklentisi & 0,834 & 0,888 & 0,665 \\
\hline Sosyal Etki & 0,846 & 0,905 & 0,761 \\
\hline Çaba Beklentisi & 0,870 & 0,911 & 0,720 \\
\hline
\end{tabular}

Bir sonraki adımda her bir değişkenin farklı bir kavramı ölçtüğü anlamına gelen ayrışma (diskriminant) geçerliği sonuçları incelenmelidir. Ayrışma geçerliği için 3 farklı kriterin analizi gerekmektedir: Fornell-Larcker kriteri, çapraz yük değerleri, ve Heterotrait-Monotrait (HTMT). Fornell-Larcker kriterine göre her bir yapı için hesaplanan AVE değerlerinin kareköklerinin diğer yapılarla olan korelasyonlarından yüksek olması gerekmektedir (Henseler, Hubona ve Ray, 2016). Örnek olarak Tablo 3 incelendiğinde AL değişkenine ait AVE değerinin karekökü olan 0,820 değeri, AL'nin diğer değişkenlerle olan korelasyonlarından yüksek olmaktadır. Diğer değişkenler için de benzer durum geçerli olduğundan Fornell-Larcker kriteri sağlanmış olmaktadır. 


\section{Tablo 3. Fornell-Larcker Criterion}

\begin{tabular}{|c|c|c|c|c|c|c|c|c|}
\hline & AL & DN & GÜ & GVM & HM & PB & SE & ÇB \\
\hline AL & $\mathbf{0 , 8 2 0}$ & & & & & & & \\
\hline DN & 0,678 & $\mathbf{0 , 9 0 0}$ & & & & & & \\
\hline GÜ & 0,391 & 0,421 & $\mathbf{0 , 8 0 7}$ & & & & & \\
\hline GVM & 0,176 & 0,207 & 0,707 & $\mathbf{0 , 9 1 5}$ & & & & \\
\hline HM & 0,627 & 0,640 & 0,323 & 0,152 & $\mathbf{0 , 9 6 3}$ & & & \\
\hline PB & 0,674 & 0,630 & 0,418 & 0,215 & 0,628 & $\mathbf{0 , 8 1 5}$ & & \\
\hline SE & 0,339 & 0,358 & 0,262 & 0,237 & 0,283 & 0,377 & $\mathbf{0 , 8 7 3}$ & \\
\hline ÇB & 0,433 & 0,523 & 0,311 & 0,140 & 0,458 & 0,509 & 0,223 & $\mathbf{0 , 8 4 9}$ \\
\hline
\end{tabular}

Çapraz yüklere ilişkin analiz çapraz tablo analizinde gösterilmektedir (EK 1). Buna göre her bir değişkene ait madde yüklerinin diğer değişkenlerdeki çapraz yüklerden büyük olması gerekmektedir. Tablo 4'de yer alan değerler incelendiğinde bu kriterin de sağlandığ anlaşılmaktadır.

HTMT kriteri modelde yer alan bütün değişkenlerin korelasyonlarının ortalamasının her bir değişkene ait maddelerin korelasyonları ile elde edilen geometrik ortalamalarına oranıdır. 0.85 eşik değer olmak üzere bütün HTMT değerlerinin 0.85in altında olması gerekmektedir. Tablo 4'de HTMT tablosu incelendiğinde GÜ ve GVM arasında her ne kadar eşik değerin altında olsa da 0.8lik bir ilişki olduğu görülmektedir. Ancak Henseler, Hubona ve Ray (2016) kavramsal olarak iki değişken arasında yakın bir ilişkinin olması durumunda eşik değerin 0,9 olarak kabul edilebileceğini ifade etmektedir. Tablo 5’de HTMT kriterinin de karşılandığı görülmektedir. Bütün kriterlere ait değerlerin sonuçlarına göre yapı geçerliğin sağlandığı anlaşılmaktadır (Hair vd., 2016). 
Tablo 4. Heterotrait-Monotrait Ratio (HTMT)

\begin{tabular}{c|c|c|c|c|c|c|c|c|}
\hline & AL & DN & G̈̈ & GVM & HM & PB & SE & ÇB \\
\hline AL & & & & & & & & \\
\hline $\mathbf{D N}$ & 0,760 & & & & & & & \\
\hline $\mathbf{G U ̈}$ & 0,428 & 0,441 & & & & & & \\
\hline $\mathbf{G V M}$ & 0,200 & 0,225 & 0,801 & & & & & \\
\hline $\mathbf{H M}$ & 0,694 & 0,679 & 0,326 & 0,161 & & & & \\
\hline $\mathbf{P B}$ & 0,783 & 0,693 & 0,465 & 0,249 & 0,678 & & & \\
\hline $\mathbf{S E}$ & 0,397 & 0,395 & 0,298 & 0,268 & 0,307 & 0,435 & & \\
\hline $\mathbf{C B}$ & 0,498 & 0,582 & 0,342 & 0,155 & 0,500 & 0,580 & 0,253 & \\
\hline
\end{tabular}

Ölçüm modelinin analizi ile güvenirlik geçerlik sonuçları elde edildikten sonra yapısal modelin test edilmesi gerekmektedir. Ancak yapısal modelin testinden önce doğrusallık probleminin olup olmadığı incelenmelidir. Bu bağlamda her bir tahminleyici değişken ile tahmini yapılan değişkenin birbirlerinden ayrılması gerekir. PLS algoritması sonucu elde edilen sonuçlar içerisinde Inner VIF değerleri bu ayrışmanın gerçekleşip gerçekleşmediğini göstermektedir. EK 2'de verilen değerler incelendiğinde bütün ilişkilere ait değerlerin 5 eşik değerinin altında olduğu görülmektedir (Hair vd., 2016). Dolayısıyla modelin doğrusallık problemi olmadığı anlaşılmaktadır.

Tablo 5'de uyum iyiliği indeksi (GoF), $\mathrm{R}^{2}$ ve $\mathrm{Q}^{2}$ değerleri yer almaktadır. Tenenhaus vd., (2005) GoF değerinin hesaplanabilmesi için $R^{2}$ değerlerinin ortalaması ile AVE değerlerinin ortalamasının çarpımı sonucu elde edilen değerin karekökünün bulunması şeklinde bir yöntem geliştirmiştir. Buna göre sonuçlar $\mathrm{GoF}=0,1$ (düşük); $\mathrm{GoF}=0,25$ (orta); $\mathrm{GoF}=0,36$ (yüksek) olmak üzere uyum derecelerini göstermektedir. Dolayısıyla bu çalışmada hesaplanan GoF değeri 0,41 olduğundan araştırma modelinin yüksek uyum derecesinde olduğu ortaya çıkmaktadır.

$\mathrm{R}^{2}$ değeri bir olgunun ilişkili değerler tarafından ne kadarının açıklanabildiğini göstermektedir. Yine bu noktada Chin (1998) $R^{2}$ değer aralıklarını 0,19 (zayıf); 0,33 (orta) ve 0, 67 (yüksek) olarak tanımlamaktadır. Çalışmada açıklanmak istenen temel değişken olan DN'ye ait $\mathrm{R}^{2}$ değeri yaklaşık \%60 olarak hesaplanmaktadır. Başka bir deyişle model içerisinde DN'nin \%60'ı ilişkili diğer değiş̧kenlerle açıklanabilmektedir. Bu da yüksek bir değer olarak karşımıza çıkmaktadır.

PLS-YEM'de yapısal modelin analizi için kullanılan diğer bir değer olan $Q^{2}$, modelin tahmin gücü analizi için kullanılmakta ve ulaşılan değerin 0 'dan büyük olması beklenmektedir. Blindfolding adı verilen işlemin sonucunda ulaşlan bu değer 0'dan ne kadar büyük olursa 
modelin tahmin gücü de o kadar iyi anlamına gelmektedir. Söz konusu ana değişken olan DN’ye ait $\mathrm{Q}^{2}$ değeri 0,45 olarak hesaplanmıştır. Bu doğrultuda $\mathrm{DN}$ açıklanmaya çalışılan temel değişken olduğundan modelin tahmin gücünün yüksek olduğu sonucuna ulaşılmaktadır.

Tablo 5. Uyum İyiliği İndeksi (GoF), R Kare ve Q Kare Değerleri

\begin{tabular}{|c|c|c|c|}
\hline & AVE & R Kare & $\mathbf{Q}^{\mathbf{2}}$ \\
\hline AL & $\mathbf{0 , 6 7 3}$ & 0,153 & 0,094 \\
\hline DN & $\mathbf{0 , 8 1 0}$ & 0,597 & 0,450 \\
\hline GÜ & $\mathbf{0 , 6 5 2}$ & 0,097 & 0,055 \\
\hline GVM & $\mathbf{0 , 8 3 7}$ & & \\
\hline HM & $\mathbf{0 , 9 2 7}$ & 0,023 & 0,018 \\
\hline PB & $\mathbf{0 , 6 6 5}$ & & \\
\hline SE & $\mathbf{0 , 7 6 1}$ & & \\
\hline ÇB & $\mathbf{0 , 7 2 0}$ & & \\
\hline Ort. & 0,756 & 0,22 & \\
\hline
\end{tabular}

Çarpım

$$
0,16443
$$

GoF $\quad 0,41$

Değişkenlerin $\mathrm{R}^{2}$ 'deki etkisini açıllaması açısından önemli olan $\mathrm{f}^{2}$ etki büyüklüğünün Hair vd., (2016) tarafından önerildiği üzere analizinin yapılması gerekmektedir. $\mathrm{f}^{2}$ değeri, $\mathrm{R}^{2}$ 'deki varyans artışını ifade etmektedir. Buna göre $\mathrm{R}^{2}$ üzerinde etkisi olan bir değişkene ait $\mathrm{f}^{2}$ değeri ilişkili değişkenin modelden çıkarılmasıyla elde edilen $\mathrm{R}^{2}$ değerinden ilişkili değişken modeldeyken elde edilen $\mathrm{R}^{2}$ değerinin çıkarılmasıyla elde edilen sonucun, ilişkili değişken modeldeyken elde edilen $\mathrm{R}^{2}$ değerinin 1'den farkına oranlanmasıyla hesaplanmaktadır. Cohen (1988) $\mathrm{f}^{2}$ için 0,35 (yüksek); 0,15 (orta) ve 0,02 (düşük) değerlerini ideal değerler olarak önermektedir. Bu çalışmada DN'ye ait $\mathrm{R}^{2}$ üzerinde en büyük etkiye sahip değilken $\mathrm{AL}(0,11)$ olmaktadır (EK 3). Buradan hareketle AL'nin modelden çıkarılması ile DN'ye ait $\mathrm{R}^{2} 0,11$ kadar azalacaktır. Diğer bütün ikili ilişkiler baz alındığında ise GÜ’nin AL'nin $\mathrm{R}^{2}$ değeri üzerindeki etkisi $(0,18)$ modeldeki en yüksek etki büyüklügü olarak karşımıza çıkmaktadır.

Yapısal modelin testindeki son aşama ise hipotezlerin incelenmesidir. Bu bağlamda hipotezlerin testi için 5000 örneklem ile bootstraping (yeniden örnekleme) yöntemi kullanılır ve sonuçlar elde edilen standart hatalara dayanmaktadır (Hair vd., 2016). Standart hata değerleri ile elde edilen $\mathrm{t}(>1.96)$ ve $\mathrm{p}(<0,05)$ istatistik değerleri ile de öngörülen ilişkilerin desteklenip desteklenmediği incelenir. Bu çalışmada kurulan hipotezlerin birçoğunun aracılık hipotezi olduğu düşünüldüğünde bazı farklı analizlerin de gerçekleştirilmesi gerekmektedir. Bu bağlamda aracılık hipotezleri Baron ve Kenny (1986) yöntemiyle değerlendirilecektir. Buna göre aracılık ilişkileri incelenirken toplam etkiler, doğrudan etkiler ve dolaylı etkiler 
tablolarından yararlanılacaktır. Diğer hipotezler ise doğrudan etkiler tablosunda yer alan değerlere göre incelenecektir. Buradan hareketle $\mathrm{H} 1, \mathrm{H} 2$ ve $\mathrm{H} 3$ hipotezleri için direkt etkiler tablosu değerlendirilirken, H4, H5 ve H6 hipotezleri için ise toplam etkiler, doğrudan etkiler ve dolaylı etkiler tabloları değerlendirilmektedir.

Tablo 6' da doğrudan etkiler yer almaktadır. Tabloda yer alan değerler incelendiğinde HM- $>\mathrm{DN}$ $\left(\beta=0,243 ; \mathrm{p}=0,00^{\star \star \star}\right), \mathrm{PB}->\left(\beta=0,104 ; \mathrm{p}=0,05^{\star}\right)$ ve $\mathrm{SE}->\mathrm{DN}\left(\beta=0,082 ; \mathrm{p}=0,05^{\star}\right)$ yollarının desteklendiği görülmektedir. Buradan hareketle $\mathrm{H} 1, \mathrm{H} 2$ ve $\mathrm{H} 3$ hipotezleri kabul edilmektedir.

Tablo 6. Doğgrudan Etkiler (Yol Katsayıları)

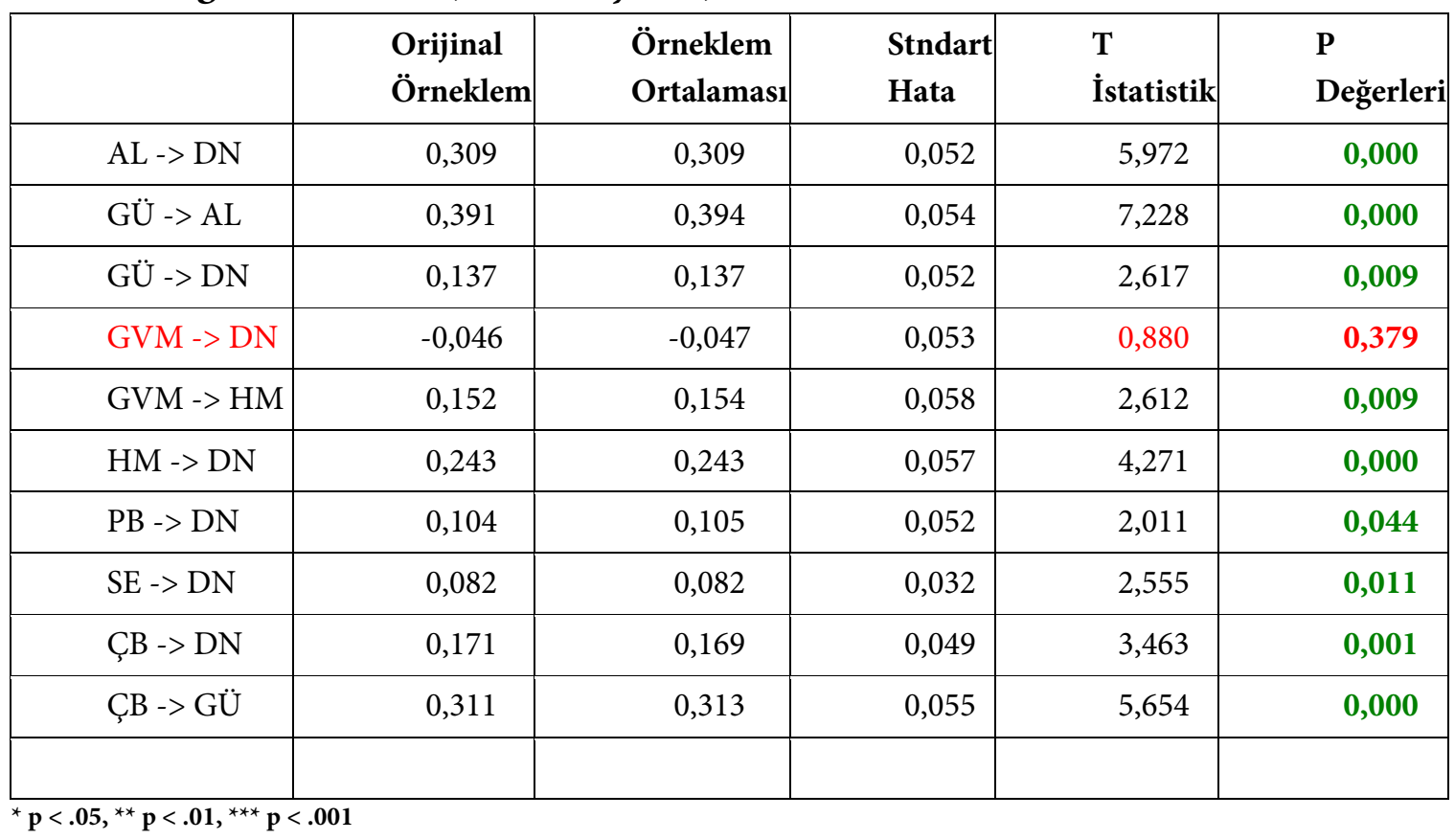

Toplam etki aracı değişkenin ilişkiye dâhil edilmediği durumda açılayıcı değişkenin bağımlı değişken üzerindeki etkisini ifade etmektedir (Doğan, 2019). Dolaylı etki ise bağımsız değişkenin aracı değişken üzerinden bağımlı değişkene olan etkisini göstermektedir. Son olarak doğrudan etki toplam etkiden dolaylı etkinin çıkarılmasıyla bulunur. Aracılık hipotezlerinde bu üç ilişkiye ait değerlerin anlamlı olması gerekmektedir. 3 etkinin anlamlı olması durumunda aracı değişkenin kısmi aracılık etkisinden söz edilmektedir. Ancak toplam etkiler ve spesifik etkiler anlamlı iken doğrudan etkiler anlamsız çıkarsa, bu noktada aracı değişkenin tam aracılığından bahsedilmektedir. Çünkü aracı değişken olmadan bağımsız değişkenin bağımlı değişken üzerinde anlamlı bir etkisi olmamaktadır. Bütün bu anlatılanlar ışığında H5, H6 ve H7 hipotezleri için GÜ->AL, AL->DN ve GÜ->AL->DN; ÇB -> GÜ, GÜ->DN ve - ÇB -> GÜ $->\mathrm{DN}$; GVM -> HM, HM->DN ve GVM $->\mathrm{HM}->$ DN ilişkileri incelenmelidir. Öncelikle Tablo 6 dikkate alındığında GÜ->AL $\left(\beta=0,391 ; p=0,00^{* *}\right), \operatorname{AL}->D N\left(\beta=0,309 ; p=0,00^{* * *}\right)$, ÇB -> GÜ $\left(\beta=0,311 ; p=0,00^{\star * \star}\right), G \ddot{U}->D N\left(\beta=0,137 ; p=0,01^{\star *}\right), \operatorname{GVM}->\operatorname{HM}\left(\beta=0,152 ; p=0,01^{\star \star}\right)$ ve $H M->D N\left(\beta=0,243 ; p=0,00^{\star * \star}\right)$ ilişkilerinin desteklendiği görülmektedir. Burada $D N$ üzerinde en büyük etki AL değişkenine ait olmaktadır. HM değişkeni de bir diğer önemli açıklayıcı olmaktadır. Diğer ilişkiler incelendiğinde ise en büyük etki GÜ’nin AL üzerindeki 
etkisinde görülmektedir. Tablo 7'de toplam etkilere bakılacak olursa GVM $>$ DN $(\beta=-0,009$; $\mathrm{p}=0,867)$ ilişkisi dışında yer alan diğer bütün ilişkilerin desteklendiği görülmektedir. $\mathrm{Bu}$ noktada GVM -> HM -> DN yolu düşünüldüğünde GVM'nin spesifik dolaylı etkiler tablosunda (Tablo 11) DN üzerindeki etkisinin $\left(\beta=0,037, \mathrm{p}=0,026^{*}\right)$ anlamlı olmasından dolayı HM'nin GVM ile DN arasındaki ilişkide tam aracılık etkisinin olduğu anlaşılmaktadır. Çünkü GVM ile DN arasındaki ilişkide HM'nin olmadığı durumda yani Tablo 7’de gösterildiği gibi GVM'nin etkisi desteklenmemektedir. Dolayısıyla H5 hipotezi desteklenmektedir ve tam aracılıktan söz edilmektedir. Tablo 8'de H4 ve H6 hipotezlerinin de desteklendiği görülmektedir. Bir başka deyişle AL, GÜ ve DN arasında $\left(\beta=0,121, p=0,00^{* * *}\right)$ ve GÜ, ÇB ile DN arasında $(\beta=0,042$, $\left.\mathrm{p}=0,019^{\star}\right) \mathrm{kısmi}$ aracılık ilişkisi vardır. Aracılık hipotezlerinin yorumlaması işe şu şekilde yapılabilmektedir:

H4: GÜ ile DN arasındaki ilişkide AL'de gerçekleşecek 1 birimlik artış GÜ'nün DN üzerindeki etkisini 0,121 arttıracaktır.

H5: GVM ile DN arasındaki ilişkide HM'de gerçekleşecek 1 birimlik artış GVM'nin DN üzerindeki etkisini 0,037 arttıracaktır.

H6: ÇB ile DN arasındaki ilişkide GÜ’de gerçekleşecek 1 birimlik artış ÇB’nin DN üzerindeki etkisini 0, 042 arttıracaktır.

Tablo 7. Toplam Etkiler

\begin{tabular}{|c|c|c|c|c|c|}
\hline & $\begin{array}{l}\text { Orijinal } \\
\text { Örneklem }\end{array}$ & $\begin{array}{l}\text { Örneklem } \\
\text { Ortalaması }\end{array}$ & $\begin{array}{l}\text { Standart } \\
\text { Hata }\end{array}$ & \begin{tabular}{l|}
$\mathrm{T}$ \\
İstatistik
\end{tabular} & $\begin{array}{l}\mathbf{P} \\
\text { Değerleri }\end{array}$ \\
\hline $\mathrm{AL}->\mathrm{AL}$ & 0,309 & 0,309 & 0,052 & 5,972 & 0,000 \\
\hline GÜ -> AL & 0,391 & 0,394 & 0,054 & 7,228 & 0,000 \\
\hline GÜ -> DN & 0,257 & 0,259 & 0,054 & 4,727 & 0,000 \\
\hline GVM -> DN & $-0,009$ & $-0,010$ & 0,056 & 0,168 & 0,867 \\
\hline GVM -> HM & 0,152 & 0,154 & 0,058 & 2,612 & 0,009 \\
\hline $\mathrm{HM}->\mathrm{DN}$ & 0,243 & 0,243 & 0,057 & 4,271 & 0,000 \\
\hline $\mathrm{PB}->\mathrm{DN}$ & 0,104 & 0,105 & 0,052 & 2,011 & 0,044 \\
\hline $\mathrm{SE}->\mathrm{DN}$ & 0,082 & 0,082 & 0,032 & 2,555 & 0,011 \\
\hline $\mathrm{C} B$-> AL & 0,122 & 0,124 & 0,031 & 3,935 & 0,000 \\
\hline $\mathrm{C} B \mathrm{~B}->\mathrm{DN}$ & 0,304 & 0,304 & 0,054 & 5,638 & 0,000 \\
\hline ÇB -> GÜ & 0,311 & 0,313 & 0,055 & 5,654 & 0,000 \\
\hline & & & & & \\
\hline
\end{tabular}


Tablo 8. Spesifik Dolayl Etkiler

\begin{tabular}{|c|c|c|c|c|c|}
\hline & $\begin{array}{c}\text { Orijinal } \\
\text { Örneklem }\end{array}$ & \begin{tabular}{c|} 
Örneklem \\
Ortalaması
\end{tabular} & $\begin{array}{c}\text { Stndart } \\
\text { Hata }\end{array}$ & $\begin{array}{c}\mathrm{T} \\
\text { İstatistik }\end{array}$ & $\begin{array}{c}\mathbf{P} \\
\text { Değerleri }\end{array}$ \\
\hline ÇB -> GÜ -> AL & 0,122 & 0,124 & 0,031 & 3,935 & 0,000 \\
\hline$G \ddot{U}->A L->D N$ & 0,121 & 0,122 & 0,027 & 4,546 & 0,000 \\
\hline $\begin{array}{l}\mathrm{C} B \text {-> GÜ -> AL -> } \\
\text { DN }\end{array}$ & 0,038 & 0,038 & 0,011 & 3,270 & 0,001 \\
\hline ÇB -> GÜ ->DN & 0,042 & 0,043 & 0,018 & 2,353 & 0,019 \\
\hline GVM $>\mathrm{HM}->\mathrm{DN}$ & 0,037 & 0,037 & 0,017 & 2,233 & 0,026 \\
\hline
\end{tabular}

Son olarak bu çalışmada çoklu grup analizi (Multi Group Analysis-MGA) uygulanmıştır. SmartPLS paket programında yer alan Multi Group Analysis-MGA işlemi ile çoklu grup analizi kolaylıkla gerçekleştirilebilmekte ve tanımlı ilişkiler üzerinde hangi faktörlerin moderatör etkisinin olduğu incelenebilmektedir. Bu çalışma kapsamında Teknoloji Hazır Olma İndeksi'nin modelde yer alan ilişkiler üzerinde moderatör etkisinin olup olmadığına bakılmıştır. Öncelikle SPSS paket programından faydalanarak K-Means Cluster analizi yapılarak örneklem teknolojiye hazır olanlar (Grup 1) ve teknolojiye hazır olmayanlar (Grup 2) olarak iki gruba ayrılmıştır. Yol katsayılarının ( $\beta$ ) geçerliğinin analizi için bootstraping yöntemi ile elde edilen $t$ ve $p$ istatistik değerleri her bir grup için kıyaslanmıştır (Tablo 9 ve Tablo 10). Buna göre GÜ->DN, HM- $>$ DN, PB- $>$ DN, SE- $>$ DN ve ÇB- $>$ DN yolları iki grup arasında farklılık göstermektedir. Ancak bir sonraki adımda farklılıkların anlamlı olup olmadığında bakılmalıdır. Dolayısıyla son olarak Tablo 11'de görüldüğü üzere gruplar arasındaki farklılıkların anlamlı olup olmadığı parametrik test sonuçlarına göre incelenebilmektedir.

Tablo 9. Teknolojiye Hazır Olma Seviyesi Yüksek Olanlar (Grup 1)

\begin{tabular}{|c|c|c|c|c|c|}
\hline & $\begin{array}{l}\text { Orijinal } \\
\text { Örneklem }\end{array}$ & $\begin{array}{l}\text { Örneklem } \\
\text { Ortalaması }\end{array}$ & $\begin{array}{l}\text { Standart } \\
\text { Hata }\end{array}$ & T İstatistik & P Değerleri \\
\hline Alışkanlık -> Davranışsal Niyet & 0,321 & 0,321 & 0,062 & 5,193 & 0,000 \\
\hline Güven -> Alışkanlık & 0,348 & 0,356 & 0,075 & 4,658 & 0,000 \\
\hline Güven -> Davranıșsal Niyet & 0,155 & 0,158 & 0,078 & 1,995 & 0,046 \\
\hline $\begin{array}{l}\text { Güvenlik ve Mahremiyet -> } \\
\text { Davranışsal Niyet }\end{array}$ & 0,017 & 0,010 & 0,081 & 0,214 & 0,831 \\
\hline $\begin{array}{l}\text { Güvenlik ve Mahremiyet -> Hazsal } \\
\text { Motivasyon }\end{array}$ & 0,146 & 0,149 & 0,079 & 1,850 & 0,064 \\
\hline $\begin{array}{l}\text { Hazsal Motivasyon -> Davranışsal } \\
\text { Niyet }\end{array}$ & 0,313 & 0,311 & 0,067 & 4,682 & 0,000 \\
\hline $\begin{array}{l}\text { Performans Beklentisi -> Davranışsal } \\
\text { Niyet }\end{array}$ & 0,009 & 0,012 & 0,070 & 0,129 & 0,897 \\
\hline Sosyal Etki -> Davranışsal Niyet & 0,097 & 0,100 & 0,046 & 2,132 & 0,033 \\
\hline Çaba Beklentisi -> Davranışsal Niyet & 0,065 & 0,064 & 0,060 & 1,097 & 0,273 \\
\hline Çaba Beklentisi -> Güven & 0,318 & 0,322 & 0,066 & 4,796 & 0,000 \\
\hline $\begin{array}{l}\text { Çaba Beklentisi -> Performans } \\
\text { Beklentisi }\end{array}$ & 0,416 & 0,420 & 0,062 & 6,686 & 0,000 \\
\hline
\end{tabular}


Tablo 10. Teknolojiye Hazır Olma Seviyesi Düşük Olanlar (Grup 2)

\begin{tabular}{|c|c|c|c|c|c|}
\hline & $\begin{array}{l}\text { Orijinal } \\
\text { Örneklem }\end{array}$ & $\begin{array}{l}\text { Örneklem } \\
\text { Ortalaması }\end{array}$ & $\begin{array}{c}\text { Standart } \\
\text { Hata }\end{array}$ & $\begin{array}{c}\mathbf{T} \\
\text { Istatistik }\end{array}$ & \begin{tabular}{|c}
$\mathbf{P}$ \\
Değerleri
\end{tabular} \\
\hline Alışkanlık -> Davranışsal Niyet & 0,235 & 0,236 & 0,082 & 2,860 & 0,004 \\
\hline Güven -> Alışkanlık & 0,438 & 0,447 & 0,073 & 5,983 & 0,000 \\
\hline Güven -> Davranışsal Niyet & 0,124 & 0,119 & 0,067 & 1,841 & 0,066 \\
\hline $\begin{array}{l}\text { Güvenlik ve Mahremiyet -> Davranışsal } \\
\text { Niyet }\end{array}$ & $-0,099$ & $-0,092$ & 0,076 & 1,310 & 0,190 \\
\hline $\begin{array}{l}\text { Güvenlik ve Mahremiyet -> Hazsal } \\
\text { Motivasyon }\end{array}$ & 0,159 & 0,167 & 0,100 & 1,594 & 0,111 \\
\hline Hazsal Motivasyon -> Davranışsal Niyet & 0,088 & 0,090 & 0,088 & 1,002 & 0,317 \\
\hline $\begin{array}{l}\text { Performans Beklentisi -> Davranışsal } \\
\text { Niyet }\end{array}$ & 0,255 & 0,259 & 0,086 & 2,957 & $\mathbf{0 , 0 0 3}$ \\
\hline Sosyal Etki -> Davranışsal Niyet & 0,075 & 0,072 & 0,050 & 1,503 & 0,133 \\
\hline Çaba Beklentisi -> Davranışsal Niyet & 0,322 & 0,318 & 0,073 & 4,427 & 0,000 \\
\hline Çaba Beklentisi -> Güven & 0,268 & 0,279 & 0,100 & 2,681 & 0,007 \\
\hline Çaba Beklentisi -> Performans Beklentisi & 0,533 & 0,536 & 0,076 & 7,054 & 0,000 \\
\hline
\end{tabular}

${ }^{\star} \mathrm{p}<.05,{ }^{* *} \mathrm{p}<.01,{ }^{* * *} \mathrm{p}<.001$

Buna göre HM ile DN $\left(\beta=0,225, p=0,05^{\star}\right)$, PB ile $\mathrm{DN}\left(\beta=0,246, \mathrm{p}=0,05^{\star}\right)$ ve ÇB ile $\mathrm{DN}(\beta=$ $0,256, \mathrm{p}=0,05^{\star}$ ) arasındaki ilişkiler iki grup arasında farklılık gösterirken bu farklılıklar anlamlıdır (Tablo 14). Dolayısıyla teknolojiye hazır olanlar ile hazır olmayanlar arasında HM, PB ve ÇB'ye yönelik beklentiler tüketicilerin davranışsal niyeti üzerinde farklılık göstermektedir. Bu anlamlı farklılığın hangi gruba yönelik gerçekleştiği ise yine Tablo 9 ve 10'da görülebilmektedir. HM ile DN arasındaki ilişki grup 1'e göre, $\mathrm{PB}$ ve ÇB’nin DN ile ilişkisi ise grup 2'ye göre anlamlı olmaktadır. Başka bir ifade ile teknolojiye hazır olanlar için HM daha önemli bir kriter olurken, teknolojiye hazır olmayanlar için ise PB ve ÇB gibi kriterler daha önemli olmaktadır. 


\section{Tablo 11. Parametrik Test Sonuçları}

\begin{tabular}{|c|c|c|c|}
\hline & $\begin{array}{l}\text { Yol Katsayları-Fark ( | } \\
\text { THİTHİ(1.0) - THİTHİ(2.0)|) }\end{array}$ & $\begin{array}{l}\text { t-Value(THİTHİ(1.0) vs } \\
\text { THİTHİ(2.0)) }\end{array}$ & $\begin{array}{l}\text { p-Value(THİTHİ(1.0) vs } \\
\text { THİTHİ(2.0)) }\end{array}$ \\
\hline $\begin{array}{l}\text { Alışkanlık -> Davranışsal } \\
\text { Niyet }\end{array}$ & 0,086 & 0,793 & 0,428 \\
\hline Güven -> Alışkanlık & 0,090 & 0,791 & 0,430 \\
\hline Güven -> Davranışsal Niyet & 0,032 & 0,267 & 0,790 \\
\hline $\begin{array}{l}\text { Güvenlik ve Mahremiyet -> } \\
\text { Davranışsal Niyet }\end{array}$ & 0,117 & 0,932 & 0,352 \\
\hline $\begin{array}{l}\text { Güvenlik ve Mahremiyet -> } \\
\text { Hazsal Motivasyon }\end{array}$ & 0,013 & 0,099 & 0,921 \\
\hline $\begin{array}{l}\text { Hazsal Motivasyon -> } \\
\text { Davranışsal Niyet }\end{array}$ & 0,225 & 1,967 & $\mathbf{0 , 0 5 0}$ \\
\hline $\begin{array}{l}\text { Performans Beklentisi -> } \\
\text { Davranışsal Niyet }\end{array}$ & 0,246 & 2,138 & $\mathbf{0 , 0 3 3}$ \\
\hline $\begin{array}{l}\text { Sosyal Etki -> Davranışsal } \\
\text { Niyet }\end{array}$ & 0,022 & 0,298 & 0,766 \\
\hline $\begin{array}{l}\text { Çaba Beklentisi -> } \\
\text { Davranışsal Niyet }\end{array}$ & 0,256 & 2,483 & 0,013 \\
\hline Çaba Beklentisi -> Güven & 0,050 & 0,428 & 0,669 \\
\hline $\begin{array}{l}\text { Çaba Beklentisi -> } \\
\text { Performans Beklentisi }\end{array}$ & 0,117 & 1,104 & 0,270 \\
\hline
\end{tabular}

${ }^{*} \mathrm{p}<.05,{ }^{* *} \mathrm{p}<.01,{ }^{* * *} \mathrm{p}<.001$

\section{Sonuç}

$\mathrm{Bu}$ çalışmanın amacı gelecekte Nİ teknolojilerinin tüketiciler tarafından kabulüne yönelik olarak davranışsal niyetin belirlenmesidir. Çalışmada BTKKT 2 temel model kabul edilerek, Nİ teknolojilerinin kabulünde önemli rol oynayacağ 1 düşünülün güven ile güvenlik ve mahremiyet değişkenleri ilgili modele eklenmiştir. Bu yönüyle Nİ teknolojilerine yönelik literatürde gerçekleştirilen çalışmaların yoğun şekilde TKM modeline dayalı bütünleşik modeller üzerinden tüketicilerin davranışsal niyetlerinin açıklandığı gözlemlenmektedir. Ancak çeşitli alanlarda TKM modeli kullanılarak gerçekleştirilen çalışmaların tutarlı olmayan ya da karmaşık sonuçlar vermesinden dolayı (Sumak ve Sorgo, 2016), tüketici konseptini daha kapsamlı inceleyecek modellere ihtiyaç duyulmuştur. Bu bağlamda tüketici boyutu dikkate alındığında BTKKT 2 en kapsamlı model olmakta ve Nİ teknolojilerinin kabulüne yönelik çalışmalarda kendisine yer bulmalıdır. İşte bu noktada gerçekleştirilen bu çalışma literatürde bahsedilen boşluğu doldurmaya yönelik olarak BTKKT 2 ile bütünleşik bir model önerisi ve analizi şeklinde tasarlanmış olup literatüre katkı sağlamaktadır. Bir diğer katkı ise teknoloji hazır olma indeksinin moderatör etkisinin incelenmesidir. Yapılan literatür taraması dahilinde BTKKT 2 modeli çerçevesinde teknoloji hazır olma indeksinin moderatör etkisini inceleyen bir çalışmaya rastlanmazken, en yakın çalışma olarak Tsourela ve Roumeliotis, (2015) gerçekleştirdikleri ve BTKKT 1 modeli dahilinde teknoloji hazır olma indeksinin moderatör etkisini inceledikleri çalışma örnek olarak verilebilir. Dolayısıyla bu araştırma, BTKKT 2 çerçevesinde teknoloji hazır olma indeksinin moderatör etkisini inceleyen ilk çalışma olmaktadır. Ayrıca bulgular neticesinde de birçok özgün sonuca ulaşıldığ 1 ve bu bağlamda literatüre değerli katkıların yapıldığı savunulmaktadır. 
Tüketicilerin gelecekte Nİ teknolojilerinin kabulüne yönelik davranışsal niyetin incelenmesinde BTKKT 2 değişkenlerinin yanında güven ile güvenlik ve mahremiyetin uyumlu bir şekilde çalıştığı davranışsal niyete ait $R^{2}$ değeri $(0,6)$ ile anlaşılmaktadır. Ancak araştırma bulgularına göre GVM'nin DN'e ait $\mathrm{R}^{2}$ üzerindeki etkisi 0 olmaktadır (Ek 2). Ayrıca GVM davranışsal niyet üzerindeki doğrudan etkisi de anlamsız olmaktadır. Bunun önemli bir nedeni tüketicilerin henüz Nİ teknolojilerine yönelik olarak yeteri kadar bilinçli olmayışı gösterilebilir. Ancak yine bu noktada yapılan alanyazın neticesinde ilk kez GVM'nin HM aracilığılla DN üzerinde pozitif etkisinin olduğu görülmektedir. Bir başka deyişle tüketiciler geçmiş teknolojilere yönelik geliştirdikleri ve içselleştirdikleri deneyimler sonucu, gelecekte Nİ teknolojilerinin kullanımı ile keyif ve haz alacaklarına inanmakta ve bu da onların Nİ teknolojilerine karşı güvenlik ve mahremiyet konularındaki korkularını azaltmaktadır. $\mathrm{Bu}$ noktada araştırma bulguları göstermektedir ki, HM, GVM ile DN arasında tam aracılık etkisine sahiptir.

Bir diğer önemli sonuç ise tüketicilerin Nİ teknolojilere bağımlı hale geleceklerine yönelik inançlarının, GÜ’nin DN üzerindeki etkisini arttırmasıdır. Doğrudan etkilerden hatırlanacak olduğu üzere hem GÜ hem de AL, DN üzerinde pozitif ve anlamlı etkiye sahip olmaktadırlar. Bu noktada AL'ın GÜ ile DN arasındaki ilişkide kısmi aracllık etkisinin olduğu anlaşılmaktadır. Tüketicilerin Nİ teknolojilerine karşı mevcut güvenleri, onların bu teknolojilerin kullanımına yönelik olarak alışkanlık kazanacakları inancıyla güçlenmektedir. Morrison ve Firmstone (2000)'e göre güven gerçekleştirilen eylemler sonucunda alışkanlığa dönüşebilmektedir. Ayrıca alışkanlık tüketicinin geçmiş deneyimleri sonucunda geliştiği için (Limayem, Hirt ve Cheung, 2007), güvenin de bu anlamda bahsedilen deneyimlerin içerisinde geliştiği gözlemlenmektedir. Dolayısıyla tüketicilerin mevcut akıllı sistemlerin kullanımına yönelik olarak, bu sistemlerin kendilerini yarı yolda bırakmayacağı ve vaat ettiklerini kontrol edilemeseler bile yerine getirebileceklerine yönelik inançları gelişmiş olmaktadır. Bu nedenle bahsedilen inançların gelecekte Nİ teknolojilerinin kullanımı noktasında tüketicilerin bu teknolojilerin kullanımına alışkanlık kazanacakları inançlarını etkilemektedir.

Çaba beklentisi BTKKT 1 ve 2'de davranışsal niyeti açıklayan önemli değişkenlerden birisi olmaktadır. Araştırma bulgularına göre tüketici Nİ teknolojilerinin kullanımı noktasında herhangi bir zorluk yaşamayacağını düşünmektedir. Bu da tüketicilerin kendilerine olan güvenini ve mevcut deneyimleri bağlamında akıllı sistemleri kullanmada problem yaşamadıkları anlamına gelmektedir. Bunun yanında araştırma bulgularına göre GÜ, ÇB ile DN arasındaki ilişkiye kısmi aracılık etmektedir. Tüketicinin sahip olduğu kontrol inancı neticesinde Nİ teknolojilerinin kullanımına yönelik geliştirdikleri kolaylık inancı onların bu teknolojilere olan güvenlerini de arttırmaktadır. Bu güvenin oluşumunda tüketicinin sahip olduğu öz yeterlilik de etkili olmaktadır. Öz yeterliliği yüksek olan tüketicilerin, NÍ teknolojilerini kullanmaya yönelik isteklilikleri de yüksek olduğundan, kullanıma yönelik niyetin oluşumunda güvenin de etkisinin olduğu anlaşılmaktadır. Bu güven neticesinde kontrol edilemeseler bile tüketici, NI teknolojilerinin vaat ettiği aktiviteleri yerine getireceğine inanmakta ve bu da onların bu teknolojilerin kullanımının daha kolay olacağı inancını geliştirmektedir. 
Katkı düzeylerine göre sıralandığında $\mathrm{AL}, \mathrm{HM}, \mathrm{ÇB}, \mathrm{GÜ}, \mathrm{PB}$ ve SE değişkenlerinin DN üzerinde pozitif ve anlamlı katkılarının olduğu görülmektedir. Bu sonuçlar bize gelecekte NI teknolojilerinin kabulü ve kullanımı noktasında tüketicilerin deneyim, eğlence ve keyif alma, iş performanslarının artması, kullanım kolaylığı ve az da olsa çevrelerindeki insanlardan etkileneceklerine işaret etmektedir. Mevcut çalışma Ni fenomeni çerçevesinde BTKKT 2 değişkenlerini GÜ ve GVM değişkenleriyle birleştirerek özgün bir model ortaya koymuştur. Bu doğrultuda GÜ’nin Nİ teknolojilerinin kabulüne yönelik önemli değişkenlerden birisi olduğu anlaşılmaktadır (Lu, Papagiannidis ve Alamanos, 2018). Ayrıca AL bütün değişkenler içerisinde en önemli etkiye sahip değişken olarak karşımıza çıkmaktadır. Her ne kadar Nİ teknolojileri kapsamında araştırmacıların bilgisi dahilinde bu model ilk kez test edilmiş olsa da AL'nin teknoloji kabul niyetinin belirlenmesinde kritik bir faktör olarak öne çıkması noktasında genel görüş desteklenmektedir (Kim ve Malhotra, 2005; Limayem, Hirt ve Cheung, 2007; Babtista ve Oliveria, 2015).

Son olarak bu çalışmada Teknoloji Hazır Olma İndeksinin (THİ) belirlenen ilişkiler üzerindeki moderatör etkisi incelenmiştir. Araştırma bulgularına göre PB, ÇB ve HM ile DN arasındaki doğrudan ilişkiler üzerinde THİ’nin moderatör etkisi saptanmıştır. HM ile DN arasındaki ilişki teknolojiye hazır olan gruba göre (grup 1) anlamlı olurken, PB ve ÇB ile DN arasındaki ilişki ise teknolojiye hazır olmayan gruba göre (grup 2) anlamlı olmaktadır. Buradan çıkarılacak sonuç teknolojiye hazır olma seviyesi arttıkça tüketicilerin beklentilerinin toplam fayda ya da harcanacak çabaya göre beklenen haz ve eğlenceye yönelik olduğudur. Teknolojiye hazır olma seviyesi yüksek olan tüketicilerin kullanıma yönelik korku ve endişeleri daha az olduğundan yeni bir teknolojiyle etkileşime girdiklerinde elde ettikleri haz daha fazla olmaktadır. Öte yandan teknolojiye hazır olma seviyesi düştükçe Nİ teknolojilerine yönelik kontrol inancının arttığı görülmektedir. Çünkü bu tüketiciler yeni teknolojilere karşı daha çekimser ve endişe duymaktadırlar. Bundan dolayı teknolojiye hazır olma seviyesi az olan tüketiciler için bekledikleri toplam fayda ve kullanım kolaylığına yönelik inançları daha öncelikli olmaktadır. Mevcut çalışmanın en önemli kısıtı Nİ teknolojilerinin akıllı telefonlar, bazı giyilebilir akıllı cihazlar ve sağlık sektörü gibi (Aksöz, 2016; Yıldırım ve Eldin, 2018) çeşitli uygulamalar dışında, genel sistem anlamında mevcut bir şekilde hayatlarımızda yer almamasıdır. Bu noktada genel modeldeki DK ve FD değişkenlerinin incelemeye alınmaması uygun görülmüştür. Bu bağlamda sistemin ilerlemesi ve ilgili ürünlerin pazara girmesi ile ek değişkenlerin modele eklenerek Nİ teknolojilerinin benimsenmesi ve kabulüne yönelik çalışmalar yapılabilecektir.

Elde edilen bulgular ışığında gelecekte Nİ teknolojilerinin kabulüne yönelik yapılacak çalışmalarda GÜ’nin hangi boyutlarda DN üzerinde etkisinin olduğu incelenebilir. GVM genel sistem güvenliği ve mahremiyet risklerini içerirken, Nİ teknolojilerine karşı tüketicide oluşan GÜ’nin bu risklerden etkilenip etkilenmediği ayrıca bir araştırma konusu olabilir. Benzer şekilde GÜ’nin oluşumunda diğer kabul değişkenlerinin etkisinin olup olmadığı da incelenebilir.

Çalışmanın amacı ışı̆̆ında sonuçlar dikkate alındığında tüketiciler Nİ teknolojilerinden günlük yaşam kalitesini arttırmasını, fonksiyonel faydanın yanında eğlenceli ve keyif verici içerikler 
sunmasını ve belki de sosyal ortamlarda kabul görmelerine yardımcı olması gibi beklentiler içerisindedirler. Nİye ilişkin pazarlama faaliyetlerinde, Nİ teknolojilerinin benimsenmesinde ön plana çıkan bu unsurların göz önünde bulundurulması gerekmektedir.

\section{Kaynakça}

Ajzen, I. (1991). The theory of planned behavior. Organizational Behavior and Human Decision Processes, 50(2), 179-211.

Ajzen, I., \& Fishbein, M. (2005). The influence of attitudes on behavior. The Handbook of Attitudes, 173(221), 31.

Aksöz, M. (2016). Examining the adoption of intention of internet of things in healthcare technology products with innovation diffusion theory and technology acceptance model. Unpublished Master Thesis. Istanbul: Bahçeşehir University, Graduate School of Natural and Applied Sciences.

Alaba, F. A., Othman, M., Hashem, I. A. T., \& Alotaibi, F. (2017). Internet of Things security: A survey. Journal of Network and Computer Applications, 88, 10-28.

Alalwan, A. A., Dwivedi, Y. K., \& Rana, N. P. (2017). Factors influencing adoption of mobile banking by Jordanian bank customers: Extending UTAUT2 with trust. International Journal of Information Management, 37(3), 99-110.

Aldossari, M. Q., \& Sidorova, A. (2018). Consumer Acceptance of Internet of Things (IoT): Smart Home Context. Journal of Computer Information Systems, 1-11.

AlHogail, A. (2018). Improving IoT Technology Adoption through Improving Consumer Trust. Technologies, 6(3), 64.

AlHogail, A., \& AlShahrani, M. (2018, July). Building consumer trust to improve Internet of Things (IoT) technology adoption. In International Conference on Applied Human Factors and Ergonomics (pp. 325-334). Springer, Cham.

Ameen, N., Willis, R., \& Shah, M. H. (2018). An examination of the gender gap in smartphone adoption and use in Arab countries: A cross-national study. Computers in Human Behavior, 89, 148-162.

Ammar, M., Russello, G., \& Crispo, B. (2018). Internet of Things: A survey on the security of IoT frameworks. Journal of Information Security and Applications, 38, 8-27.

Attie, E., \& Meyer-Waarden, L. (2016). The Impacts of Social Value, Cognitive Factors and Well-Being on the Use of the Internet of Things and Smart Connected Objects.

Baptista, G., \& Oliveira, T. (2015). Understanding mobile banking: The unified theory of acceptance and use of technology combined with cultural moderators. Computers in Human Behavior, 50, 418-430.

Baron, R. M., \& Kenny, D. A. (1986). The moderator-mediator variable distinction in social psychological research: Conceptual, strategic, and statistical considerations. Journal of Personality and Social Psychology, 51(6), 1173.

Baudier, P., Ammi, C., \& Deboeuf-Rouchon, M. (2018). Smart home: Highly-educated students' acceptance. Technological Forecasting and Social Change. 
Belanche, D., Casaló, L. V., \& Flavián, C. (2012). Integrating trust and personal values into the Technology Acceptance Model: The case of e-government services adoption. Cuadernos de Economía y Dirección de la Empresa, 15(4), 192-204.

Brown, S. A., \& Venkatesh, V. (2005). Model of adoption of technology in households: A baseline model test and extension incorporating household life cycle. MIS quarterly, 29(3).

Liébana-Cabanillas, F., Marinković, V., \& Kalinić, Z. (2017). A SEM-neural network approach for predicting antecedents of $\mathrm{m}$-commerce acceptance. International Journal of Information Management, 37(2), 14-24.

Cisco. (2013). Embracing the Internet of Everything. White Paper.

Chin, W. W. (1998). The partial least squares approach to structural equation modeling. Modern Methods for Business Research, 295(2), 295-336.

Chipeva, P., Cruz-Jesus, F., Oliveira, T., \& Irani, Z. (2018). Digital divide at individual level: Evidence for Eastern and Western European countries. Government Information Quarterly, 35(3), 460-479.

Chong, A. Y. L., \& Chan, F. T. (2012). Structural equation modeling for multi-stage analysis on Radio Frequency Identification (RFID) diffusion in the health care industry. Expert Systems with Applications, 39(10), 8645-8654.

Cohen, J. (1988). Statistical power analysis for the behaviors science.(2nd). New Jersey: Laurence Erlbaum Associates, Publishers, Hillsdale.

Coughlan, T., Brown, M., Mortier, R., Houghton, R. J., Goulden, M., \& Lawson, G. (2012, November). Exploring Acceptance and Consequences of the Internet of Things in the Home. In 2012 IEEE International Conference on Green Computing and Communications (pp. 148-155). IEEE.

Davis, F. D. (1989). Perceived usefulness, perceived ease of use, and user acceptance of information technology. MIS quarterly, 319-340.

Deci, E. L., \& Ryan, R. M. (1985). The general causality orientations scale: Self-determination in personality. Journal of Research in Personality, 19(2), 109-134.

Doğan, D. (2019). SmartPLS ile Veri Analizi. (2. Baskı). Ankara: Zet.

Elliott, K., Meng, G., \& Hall, M. (2012). The influence of technology readiness on the evaluation of self-service technology attributes and resulting attitude toward technology usage. Services Marketing Quarterly, 33(4), 311-329.

El-Masri, M., \& Tarhini, A. (2017). Factors affecting the adoption of e-learning systems in Qatar and USA: Extending the Unified Theory of Acceptance and Use of Technology 2 (UTAUT2). Educational Technology Research and Development, 65(3), 743-763.

Falcone, R., \& Sapienza, A. (2018). On the Users' Acceptance of IoT Systems: A Theoretical Approach. Information, 9(3), 53.

Fornell, C., \& Larcker, D. F. (1981). Evaluating structural equation models with unobservable variables and measurement error. Journal of Marketing Research, 18(1), 39-50.

Gao, L., \& Bai, X. (2014). A unified perspective on the factors influencing consumer acceptance of internet of things technology. Asia Pacific Journal of Marketing and Logistics, 26(2), 211-231. 
Gao, Y., Li, H., \& Luo, Y. (2015). An empirical study of wearable technology acceptance in healthcare. Industrial Management \& Data Systems, 115(9), 1704-1723.

Fernandez-Gago, C., Moyano, F., \& Lopez, J. (2017). Modelling trust dynamics in the Internet of Things. Information Sciences, 396, 72-82.

Gartner. (2013). Forecast: The internet of things, worldwide. Retrieved from http://www.gartner.com/newsroom/id/2636073

Gefen, D., Karahanna, E., \& Straub, D. W. (2003). Trust and TAM in online shopping: an integrated model. MIS Quarterly, 27(1), 51-90.

Gong, W. (2016). The Internet of Things (IoT): What is the potential of the internet of things (IoT) as a marketing tool? (Bachelor's thesis, University of Twente).

Henseler, J., Hubona, G., \& Ray, P. A. (2016). Using PLS path modeling in new technology research: updated guidelines. Industrial Management \& Data Systems, 116(1), 2-20.

Hair Jr, J. F., Hult, G. T. M., Ringle, C., \& Sarstedt, M. (2016). A primer on partial least squares structural equation modeling (PLS-SEM). CA: Sage.

Herrero, Á., \& San Martín, H. (2017). Explaining the adoption of social networks sites for sharing user-generated content: A revision of the UTAUT2. Computers in Human Behavior, 71, 209-217.

Ramón-Jerónimo, M. A., Peral-Peral, B., \& Arenas-Gaitan, J. (2013). Elderly persons and Internet use. Social Science Computer Review, 31(4), 389-403.

Kaushik, A. K., Agrawal, A. K., \& Rahman, Z. (2015). Tourist behaviour towards self-service hotel technology adoption: Trust and subjective norm as key antecedents. Tourism Management Perspectives, 16, 278-289.

Khan, W. Z., Aalsalem, M. Y., Khan, M. K., \& Arshad, Q. (2016). Enabling consumer trust upon acceptance of IoT technologies through security and privacy model. In Advanced multimedia and ubiquitous engineering (pp. 111-117). Springer, Singapore.

Kim, S. S., \& Malhotra, N. K. (2005). A longitudinal model of continued IS use: An integrative view of four mechanisms underlying postadoption phenomena. Management Science, 51(5), 741-755.

Kuo, K. M., Liu, C. F., \& Ma, C. C. (2013). An investigation of the effect of nurses' technology readiness on the acceptance of mobile electronic medical record systems. BMC Medical Informatics and Decision Making, 13(1), 88.

Lasi, H., Fettke, P., Kemper, H. G., Feld, T., \& Hoffmann, M. (2014). Industry 4.0. Business \& Information Systems Engineering, 6(4), 239-242.

Limayem, M., Hirt, S. G., \& Cheung, C. M. (2007). How habit limits the predictive power of intention: The case of information systems continuance. MIS Quarterly, 31(4).

Lu, Y., Papagiannidis, S., \& Alamanos, E. (2018). Internet of Things: A systematic review of the business literature from the user and organisational perspectives. Technological Forecasting and Social Change, 136, 285-297.

Mardjo, A. Exploring Facebook users' willingness to accept f-commerce using the integrated unified theory of acceptance and use of technology 2 (UTAUT2), trust and risk under the moderating role of age and gender. 
Macedo, I. M. (2017). Predicting the acceptance and use of information and communication technology by older adults: An empirical examination of the revised UTAUT2. Computers in Human Behavior, 75, 935-948.

Mohammadzadeh, A. K., Ghafoori, S., Mohammadian, A., Mohammadkazemi, R., Mahbanooei, B., \& Ghasemi, R. (2018). A Fuzzy Analytic Network Process (FANP) approach for prioritizing internet of things challenges in Iran. Technology in Society, 53, 124-134.

Morosan, C., \& DeFranco, A. (2016). It's about time: Revisiting UTAUT2 to examine consumers' intentions to use NFC mobile payments in hotels. International Journal of Hospitality Management, 53, 17-29.

Morrison, D. E., \& Firmstone, J. (2000). The social function of trust and implications for ecommerce. International Journal of Advertising, 19(5), 599-623.

Ouellette, J. A., \& Wood, W. (1998). Habit and intention in everyday life: The multiple processes by which past behavior predicts future behavior. Psychological Bulletin, 124(1), 54.

Parasuraman, A. (2000). Technology Readiness Index (TRI) a multiple-item scale to measure readiness to embrace new technologies. Journal of Service Research, 2(4), 307-320.

Perera, C., Zaslavsky, A., Christen, P., \& Georgakopoulos, D. (2013). Context aware computing for the internet of things: A survey. IEEE Communications Surveys \& Tutorials, 16(1), 414-454.

Rahman, S. A., Taghizadeh, S. K., Ramayah, T., \& Alam, M. M. D. (2017). Technology acceptance among micro-entrepreneurs in marginalized social strata: The case of social innovation in Bangladesh. Technological Forecasting and Social Change, 118, 236-245.

Ringle, C.M., Wende, S., and Becker, J.-M. 2015. “SmartPLS 3.” Boenningstedt:SmartPLS $\mathrm{GmbH}$, http://www.smartpls.com.

Sicari, S., Rizzardi, A., Grieco, L. A., \& Coen-Porisini, A. (2015). Security, privacy and trust in Internet of Things: The road ahead. Computer Networks, 76, 146-164.

Shin, D. H. (2010). The effects of trust, security and privacy in social networking: A securitybased approach to understand the pattern of adoption. Interacting with Computers, 22(5), 428-438.

Shin, S., \& Lee, W. J. (2014). The effects of technology readiness and technology acceptance on NFC mobile payment services in Korea. Journal of Applied Business Research, 30(6), 1615.

Silva, B. N., Khan, M., \& Han, K. (2018). Internet of things: A comprehensive review of enabling technologies, architecture, and challenges. IETE Technical Review, 35(2), 205-220.

Simanjuntak, R. J., \& Ramantoko, G. (2016, January). Factors Affecting Purchase Intention of Consumers To Smartphone Samsung Galaxy Post Use Of Previous Smartphone. In International Conference on Transformation in Communication (ICOTIC).

Šumak, B., \& Šorgo, A. (2016). The acceptance and use of interactive whiteboards among teachers: Differences in UTAUT determinants between pre-and post-adopters. Computers in Human Behavior, 64, 602-620.

Tenenhaus, M., Vinzi, V. E., Chatelin, Y. M., \& Lauro, C. (2005). PLS path modeling. Computational Statistics \& Data Analysis, 48(1), 159-205.

Venkatesh, V., \& Davis, F. D. (2000). A theoretical extension of the technology acceptance model: Four longitudinal field studies. Management Science, 46(2), 186-204. 
Venkatesh, V., Morris, M. G., Davis, G. B., \& Davis, F. D. (2003). User acceptance of information technology: Toward a unified view. MIS Quarterly, 425-478.

Venkatesh, V., Thong, J. Y., \& Xu, X. (2012). Consumer acceptance and use of information technology: extending the unified theory of acceptance and use of technology. MIS Quarterly, 36(1), 157-178.

Verkijika, S. F. (2018). Factors influencing the adoption of mobile commerce applications in Cameroon. Telematics and Informatics, 35(6), 1665-1674.

Tsu Wei, T., Marthandan, G., Yee-Loong Chong, A., Ooi, K. B., \& Arumugam, S. (2009). What drives Malaysian $\mathrm{m}$-commerce adoption? An empirical analysis. Industrial Management \& Data Systems, 109(3), 370-388.

Wong, C. H., Wei-Han Tan, G., Loke, S. P., \& Ooi, K. B. (2014). Mobile TV: a new form of entertainment?. Industrial Management \& Data Systems, 114(7), 1050-1067.

$\mathrm{Wu}$, L.H., Wu, L.C. and Chang, S.C. (2016) 'Exploring consumers' intention to accept smartwatch', Computers in Human Behaviour, 64(November), 383-392.

XIONG, X., \& MEI, Q. (2016). Study on the Factors Influencing User's Acceptance Intention for Smart Medical and Health Care Equipment Based on UTAUT2. DEStech Transactions on Economics, Business and Management, (apme).

Yildirim, H., \& Ali-Eldin, A. M. (2018). A model for predicting user intention to use wearable IoT devices at the workplace. Journal of King Saud University-Computer and Information Sciences. 


\section{EKLER}

Ek 1. Çapraz Tablo Değerleri

\begin{tabular}{|c|c|c|c|c|c|c|c|c|}
\hline & $\mathbf{A L}$ & DN & $\mathbf{G} \ddot{\mathbf{U}}$ & GVM & HM & PB & $\mathbf{S E}$ & $\mathbf{C} \mathbf{B}$ \\
\hline AL1 & $\mathbf{0 , 8 5 3}$ & 0,611 & 0,317 & 0,124 & 0,658 & 0,636 & 0,310 & 0,452 \\
\hline AL2 & 0,772 & 0,406 & 0,298 & 0,164 & 0,471 & 0,517 & 0,229 & 0,295 \\
\hline AL3 & 0,772 & 0,543 & 0,290 & 0,117 & 0,389 & 0,473 & 0,295 & 0,239 \\
\hline AL4 & 0,878 & 0,629 & 0,372 & 0,175 & 0,523 & 0,577 & 0,272 & 0,409 \\
\hline DN1 & 0,600 & 0,916 & 0,406 & 0,201 & 0,607 & 0,600 & 0,334 & 0,493 \\
\hline DN2 & 0,577 & 0,873 & 0,368 & 0,199 & 0,547 & 0,524 & 0,354 & 0,417 \\
\hline DN3 & 0,631 & 0,928 & 0,409 & 0,222 & 0,588 & 0,585 & 0,323 & 0,491 \\
\hline DN4 & 0,633 & $\mathbf{0 , 8 8 2}$ & 0,333 & 0,124 & 0,561 & 0,555 & 0,277 & 0,478 \\
\hline GV1 & 0,201 & 0,213 & 0,644 & $\mathbf{0 , 8 8 8}$ & 0,145 & 0,247 & 0,206 & 0,157 \\
\hline GV2 & 0,129 & 0,168 & 0,638 & 0,941 & 0,142 & 0,171 & 0,233 & 0,093 \\
\hline GV3 & 0,145 & 0,182 & 0,655 & 0,914 & 0,128 & 0,163 & 0,214 & 0,127 \\
\hline GÜ1 & 0,258 & 0,291 & 0,864 & 0,678 & 0,223 & 0,306 & 0,218 & 0,264 \\
\hline GÜ2 & 0,318 & 0,354 & 0,882 & 0,668 & 0,273 & 0,344 & 0,266 & 0,251 \\
\hline GÜ3 & 0,272 & 0,281 & $\mathbf{0 , 8 3 5}$ & 0,655 & 0,182 & 0,260 & 0,261 & 0,244 \\
\hline GÜ4 & 0,223 & 0,233 & 0,793 & 0,648 & 0,155 & 0,296 & 0,233 & 0,178 \\
\hline GÜ5 & 0,297 & 0,322 & 0,745 & 0,465 & 0,254 & 0,306 & 0,139 & 0,236 \\
\hline GÜ6 & 0,432 & 0,457 & 0,710 & 0,376 & 0,379 & 0,435 & 0,165 & 0,287 \\
\hline HM1 & 0,605 & 0,598 & 0,286 & 0,093 & 0,966 & 0,610 & 0,250 & 0,447 \\
\hline HM2 & 0,608 & 0,636 & 0,328 & 0,154 & 0,971 & 0,615 & 0,277 & 0,465 \\
\hline HМ3 & 0,596 & 0,613 & 0,316 & 0,188 & 0,951 & 0,588 & 0,287 & 0,411 \\
\hline PB1 & 0,654 & 0,656 & 0,356 & 0,156 & 0,646 & 0,826 & 0,337 & 0,519 \\
\hline PB2 & 0,508 & 0,444 & 0,341 & 0,200 & 0,443 & $\mathbf{0 , 8 3 0}$ & 0,319 & 0,372 \\
\hline PB3 & 0,563 & 0,490 & 0,326 & 0,128 & 0,501 & $\mathbf{0 , 8 4 7}$ & 0,293 & 0,362 \\
\hline PB4 & 0,422 & 0,397 & 0,337 & 0,235 & 0,394 & 0,756 & 0,268 & 0,364 \\
\hline SE1 & 0,262 & 0,237 & 0,195 & 0,203 & 0,215 & 0,278 & $\mathbf{0 , 8 0 8}$ & 0,154 \\
\hline
\end{tabular}


Ek 1. (Devam) Çapraz Tablo Değerleri

\begin{tabular}{c|c|c|c|c|c|c|c|c|}
\hline SE2 & 0,295 & 0,308 & 0,192 & 0,150 & 0,218 & 0,305 & $\mathbf{0 , 9 1 0}$ & 0,167 \\
\hline SE3 & 0,322 & 0,368 & 0,285 & 0,260 & 0,295 & 0,386 & $\mathbf{0 , 8 9 6}$ & 0,248 \\
\hline ÇB1 & 0,329 & 0,408 & 0,287 & 0,143 & 0,370 & 0,422 & 0,144 & $\mathbf{0 , 8 4 8}$ \\
\hline ÇB2 & 0,339 & 0,427 & 0,310 & 0,201 & 0,375 & 0,438 & 0,197 & $\mathbf{0 , 8 0 8}$ \\
\hline ÇB3 & 0,409 & 0,494 & 0,240 & 0,072 & 0,436 & 0,457 & 0,193 & $\mathbf{0 , 9 0 1}$ \\
\hline ÇB4 & 0,390 & 0,443 & 0,218 & 0,058 & 0,372 & 0,408 & 0,224 & $\mathbf{0 , 8 3 5}$ \\
\hline
\end{tabular}

Ek 2. Inner VIF Değerleri

\begin{tabular}{c|c|c|c|c|c|c|c|c|}
\hline & AL & DN & GÜ & GVM & HM & PB & SE & ÇB \\
\hline $\mathbf{A L}$ & & 2,185 & & & & & & \\
\hline $\mathbf{D N}$ & & & & & & & & \\
\hline $\mathbf{G U ̈}$ & 1,000 & 2,464 & & & & & & \\
\hline $\mathbf{G V M}$ & & 2,095 & & & 1,000 & & & \\
\hline $\mathbf{H M}$ & & 1,944 & & & & & & \\
\hline $\mathbf{P B}$ & & 2,383 & & & & & & \\
\hline $\mathbf{S E}$ & & 1,220 & & & & & & \\
\hline $\mathbf{C B}$ & & 1,438 & 1,000 & & & 1,000 & & \\
\hline
\end{tabular}

\section{Ek 3. f kare değerleri}

\begin{tabular}{c|c|c|c|c|c|c|c|c|}
\hline & AL & DN & GÜ & GVM & HM & PB & SE & ÇB \\
\hline AL & & 0,11 & & & & & & \\
\hline DN & & & & & & & & \\
\hline GÜ & $\mathbf{0 , 1 8}$ & $\mathbf{0 , 0 2}$ & & & & & & \\
\hline GVM & & $\mathbf{0 , 0 0}$ & & & 0,02 & & & \\
\hline HM & & 0,08 & & & & & & \\
\hline PB & & $\mathbf{0 , 0 2}$ & & & & & & \\
\hline SE & & $\mathbf{0 , 0 1}$ & & & & & & \\
\hline ÇB & & 0,05 & 0,11 & & & & & \\
\hline
\end{tabular}

